


\section{CONTENTS}

Abstract
Introduction
Purpose
Structure of this report

\section{$(* * * *$ Beginning of Workbook ****)}

District Surface Water Quality-Assurance Plans .

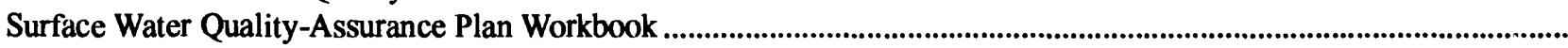

Abstract .

Introduction

Responsibilities

Collection of stage and streamflow data

Gage installation and maintenance

Measurement of stage

Gage documents.

Levels.

Site documentation.

Station descriptions

Photographs.

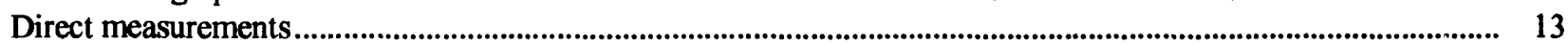

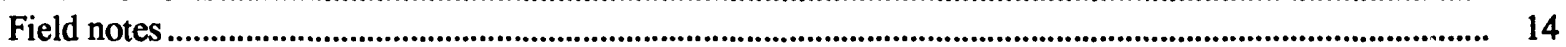

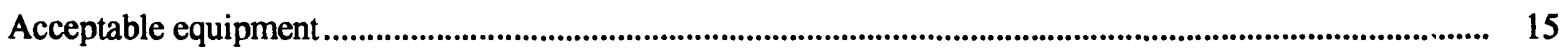

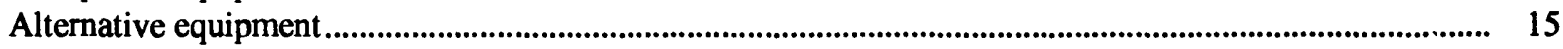

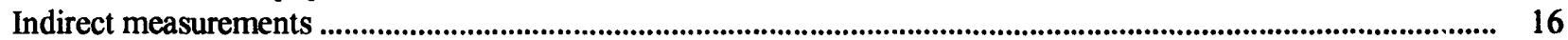

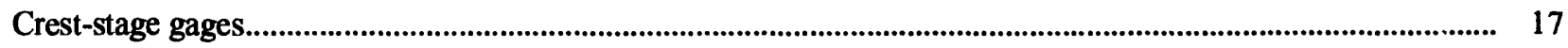

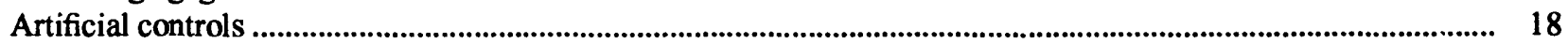

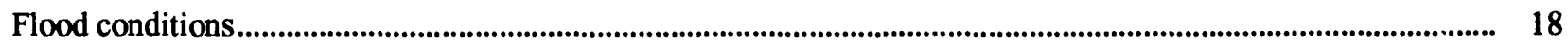

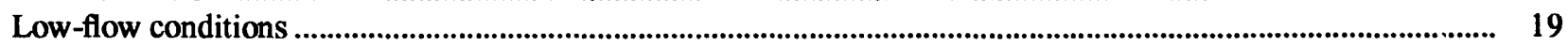

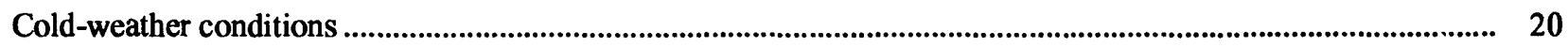

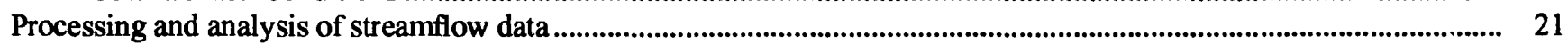

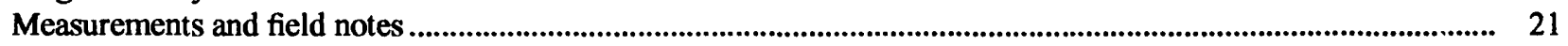

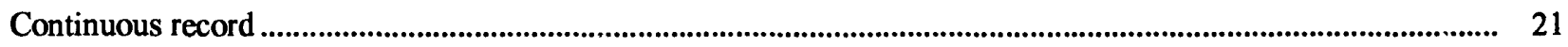

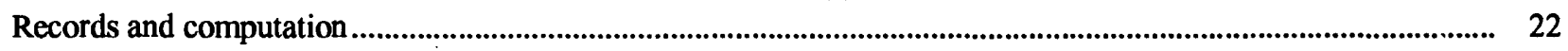

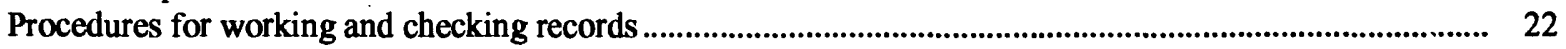

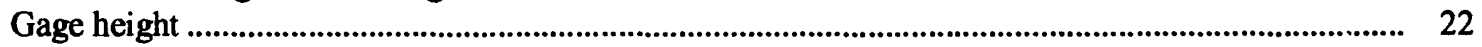

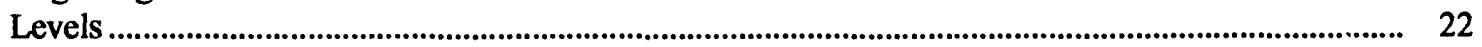

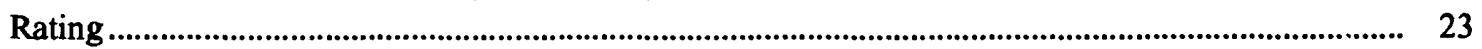

Datum corrections, gage-height corrections, and shifts ............................................................... 23

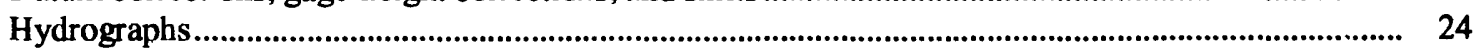

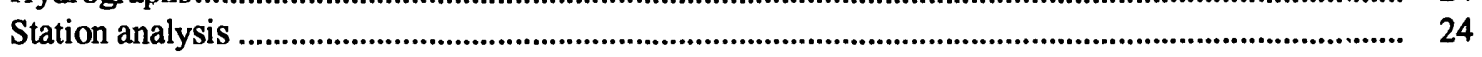

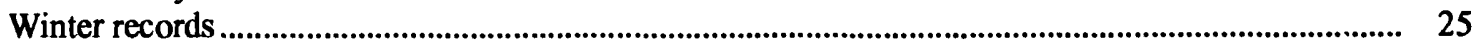

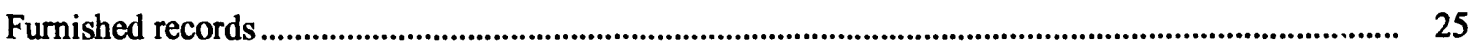

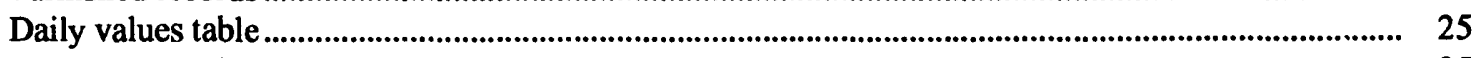

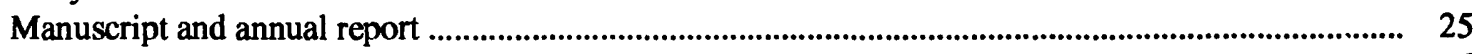

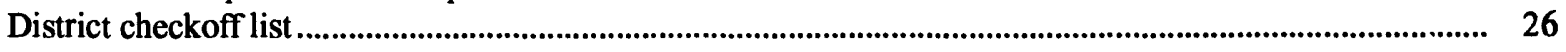

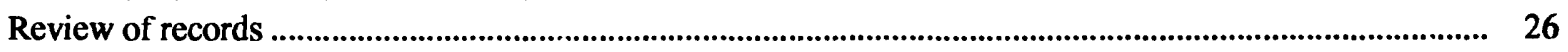

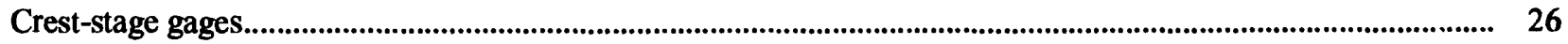

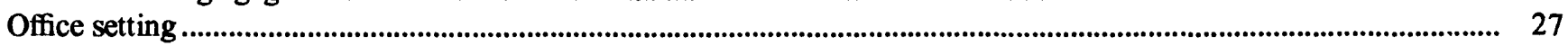

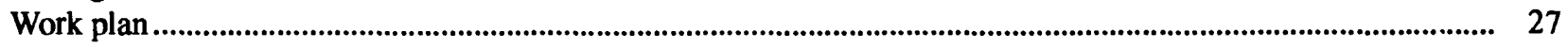




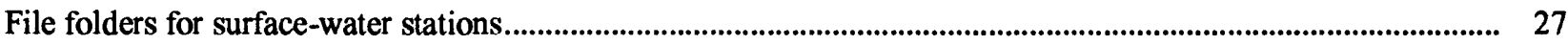

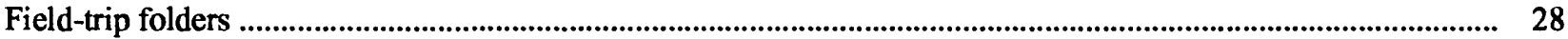

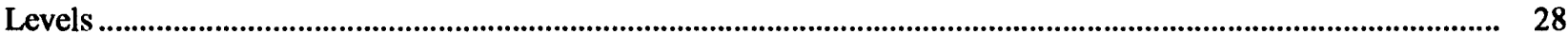

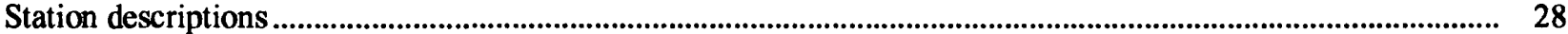

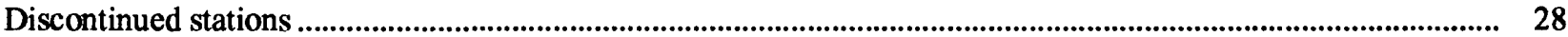

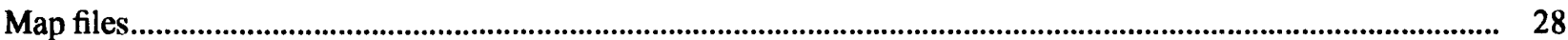

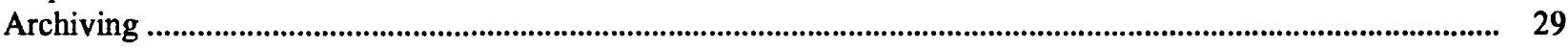

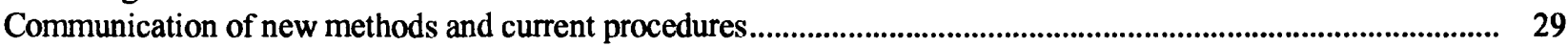

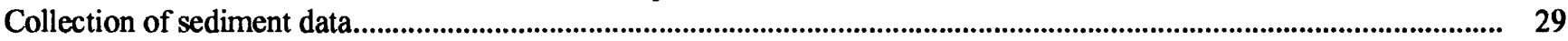

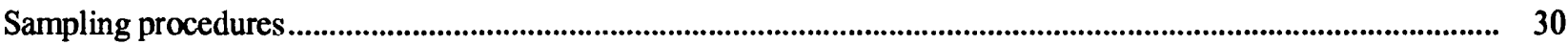

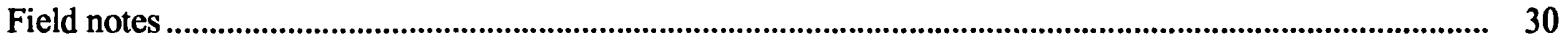

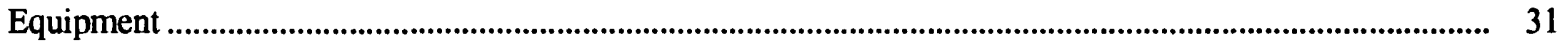

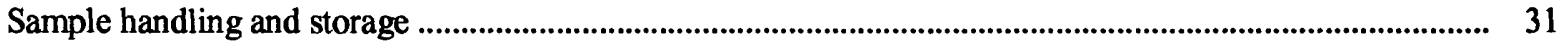

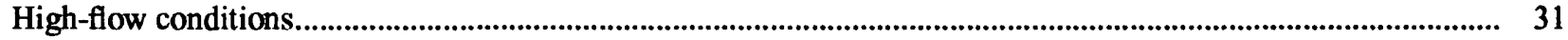

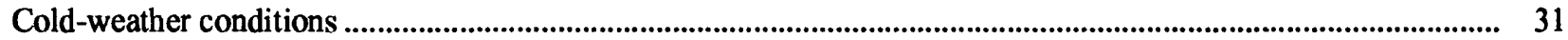

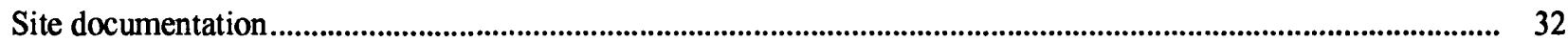

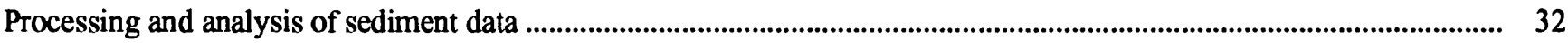

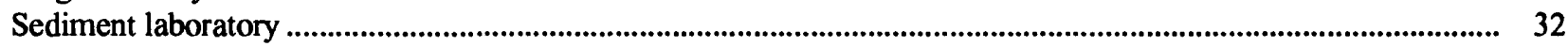

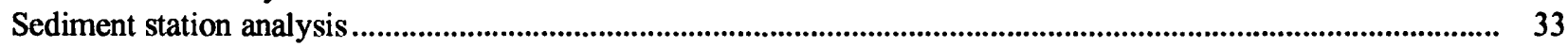

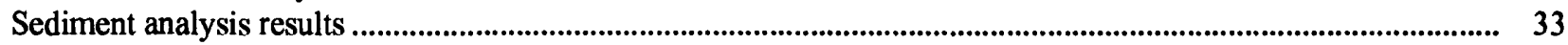

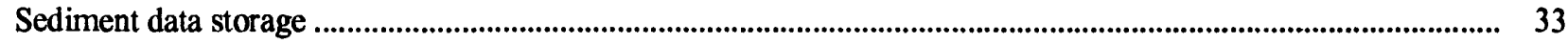

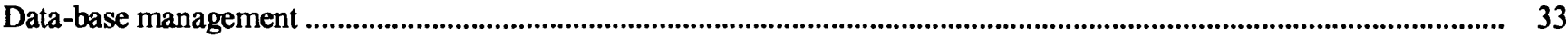

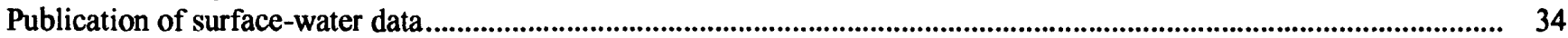

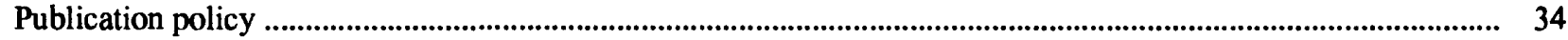

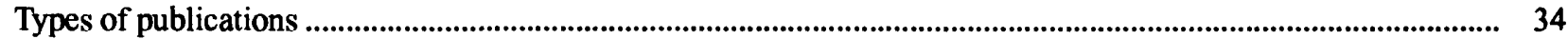

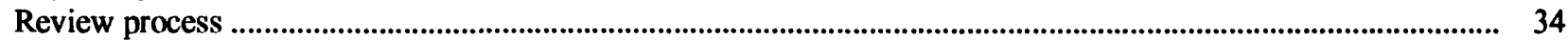

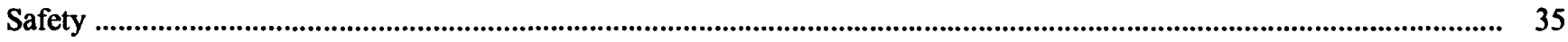

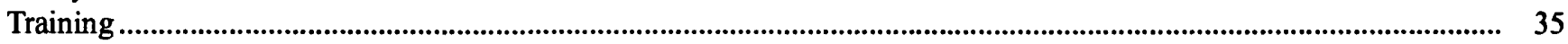

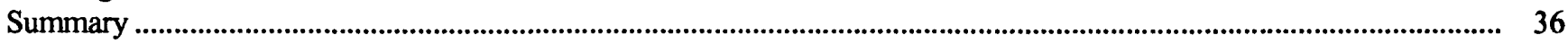

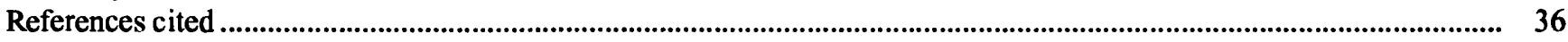

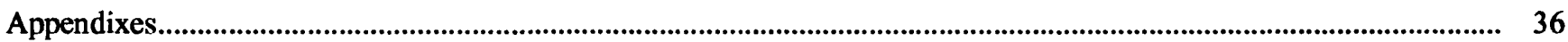

Appendix 1. Water Resources Division memorandums cited ............................................................................. 36

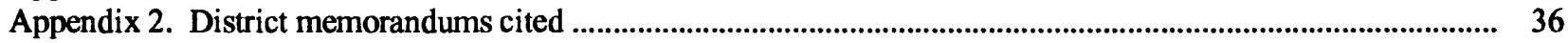

$(* * * *$ End of Workbook $* * * *)$

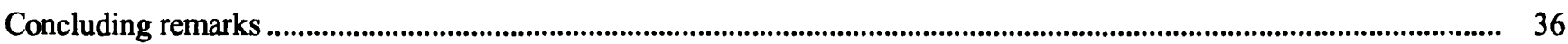

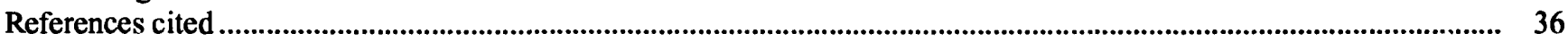

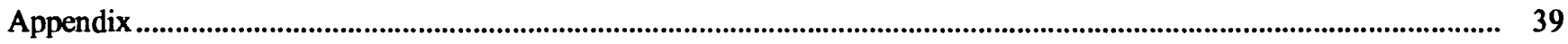

\section{FIGURE}

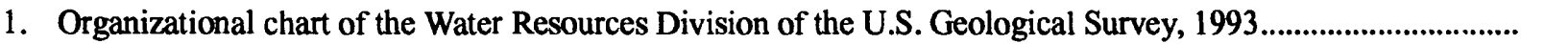




\title{
A Workbook for Preparing Surface Water Quality-Assurance Plans for Districts of the U.S. Geological Survey, Water Resources Division
}

\author{
By Donald V. Arvin
}

\section{Abstract}

The U.S. Geological Survey, Water Resources Division, has a policy that each District office is required to prepare a District Surface Water QualityAssurance Plan. The plan for each District describes the policies and procedures that ensure high quality in the collection, processing, analysis, computer storage, and publication of surface-water data. The guidelines presented in this report are structured as a workbook to provide a specific framework for Districts in preparing their District Surface Water Quality-Assurance Plans.

\section{INTRODUCTION}

The U.S. Geological Survey (USGS) collects and disseminates information about the quality and quantity of water in streams, lakes, and aquifers. As the Nation's principal earth-science agency, the USGS has a worldwide reputation for collecting accurate data and producing factual and impartial interpretive reports.

The Water Resources Division (WRD) of the USGS maintains a high level of quality of surface-water data and related products by establishing policies and procedures at the national level and by providing extensive training and experience to personnel who manage or perform surface-water activities. The Office of Surface Water (OSW) has much of the responsibility for formulating policies, developing procedures, and providing training. Because many factors differ significantly from one District to another, the OSW recognizes the benefits gained when each District complements national policies with its own policies and procedures that are suited to the local environmental conditions and to the levels of knowledge and abilities of each District's personnel. The OSW also recognizes that various approaches to collecting and analyzing hydrologic data may have equal technical validity and allow District personnel to adopt those approaches that best fit District preferences and needs.
The WRD requires each District to prenare a District Surface Water Quality-Assurance Plan (QA Plan) and to follow the policies and procedures described in its plans to ensure the quality of the surface-water data that are collected, maintained, and made available for use by others.

\section{Purpose}

The information and guidelines presented in this report are intended to serve as a framework for each District to prepare a QA Plan tailored to local conditions and requirements. The focus and structure of this report are intended to assist Districts in their $\mathrm{e} f$ forts by:

- Serving as a resource for those involvet in the collection and analysis of surface-wate- data concerning policies and procedures determined by the WRD and OSW.

- Delineating what specific topics should be addressed in a District plan, while providing the latitude for knowledgeable District personnel to determine procedures and policies that are most suitable for conditions encountered in their own District.

- Providing a means to include District, $C \times \mathrm{W}$, and WRD policies in a single document that can proceed through the review and approval process in an effective and timely manner.

\section{Scope}

This report presents an overview of WPD and OSW policies and procedures pertaining to th $\because$ collection, processing, analysis, storage, and publication of surface-water data. In addition, issues related to management of the computer data base and employee safety and training are presented. 


\section{Structure of this Report}

This report has been structured with the goal of providing each District with an effective tool for preparing a publishable QA Plan. This report provides direction on what elements are appropriate for inclusion in the QA Plan, while providing Districts the latitude to focus on methods most suitable for local conditions.

Within this report is a workbook. The workbook presents topics to be included in each QA Plan and serves as the structural template for the District plan. The workbook spells out policy and procedures determined by the WRD and OSW, then serves as a guide for Districts to describe policies and procedures that have been established at the District level. Districts prepare their surface water quality-assurance plans by completing the workbook. Throughout the workbook, Districts are asked to select one or more of the available options, draft their own description, or fill in the blanks. Once the workbook has been completed, all instructions and unused options are to be removed from the draft by the District, leaving a District Surface Water Quality-Assurance Plan that is in publishable format subject to review and approval by the OSW.

\section{DISTRICT SURFACE WATER QUALITY- ASSURANCE PLANS}

It is the responsibility of each District to ensure that District personnel are well trained in technical applications, are fully aware of their responsibilities, are well versed in policies and procedures, and are active participants in obtaining and maintaining reliable surface-water data and analytical results. A wellwritten QA Plan can be a valuable tool to help Districts meet these responsibilities.

To ensure reliability of work related to the collection, processing, analysis, storage, and publication of surface-water data, the OSW requires each District to prepare a District Surface Water Quality-Assurance Plan and make it available to each employee involved in any way with surface-water activities.

Many agencies and individuals depend on the reliability of the methods and products of the WRD. It often happens that, even within a single District office, some of the data used by one project originate as the product of another project. For this reason, the QA Plan must be a document that can be referenced and freely distributed. To meet this requirement, the document is to be published as an open-file report subject to the USGS technical review process. Because responsibilities, procedures, and equipment are subject to change, the document will be updated at least once every 3 years. Revisions to the original published document do not require publication of a new and separate open-file report. A revised version wovld retain the identification number of the original report, with the latest date of revision shown and the pevious report referenced. Revisions are subject to apnroval at the District level, although the OSW may provide input related to the plans in the course of District surfacewater activities review. It is required that the Publications Management Unit be notified that a revised version of the report has been prepared, and copies of the revised version must be frovided to the Books and Open-File Reports Section.

As the workbook found in this report is completed, Districts will provide workbook answers with the goal of making the District Surface. Water QualityAssurance Plan an asset to their overall operations. The plan should emphasize phrasing th at provides workers with clear guidelines on what should be done in the various field and office situations. For example, if field personnel arrive at a gaging station to find that a flash flood occurred during the previous 24 hours, the QA Plan should be written in such a way that field personnel can refer to the plan and clearly understand what is expected of them. Beyond stating expectations, clear guidelines can result in the added benefit of providing the means for a responsible party to determine if the work was carried out correctly and completely. Although quality-assurance plans serve many purposes, this plan should be written with the worker in mind.

As each District prepares a QA Plan, it is important to remember that the ultimate goal of the plan is to ensure the quality of USGS surface-water data. Exactly how and when data are collected and processed, procedures are performed, individuals are trained, problems are identified, issues are documented, and problems are corrected are all components of achieving that goal. As the plans are written, Districts will focus on describing policies and procedures that are currently in place and aroid including goals that are unattainable. For example, do not state that the District Surface-Water Specialist provides training by accompanying all field per onnel on one field trip each year if that particular practice has been unattainable because of time constraints and scheduling problems. Rather, if specific form of training are provided on the job by coworkers or lead technicians, this should be stated frankly. Candid descriptions of actual procedures allow District managers to assess more accurately the basic strengths and weaknesses of their program. This approach provides all personnel with a better understanding of successful methods, training needs, and the potential for erors. 
Beyond providing all District personnel clear guidance on policies and procedures related to surfacewater activities, each QA Plan provides a structural framework for periodic review of District surfacewater activities.

\section{SURFACE WATER QUALITY- ASSURANCE PLAN WORKBOOK}

The workbook section of this report begins after this paragraph. The draft of the District Surface Water Quality-Assurance Plan (QA Plan) is written by completing this workbook. All text inserted in the workbook by the District should be made to appear in the color red in the electronic version. One convenient method of making the text red is by highlighting the inserted FrameMaker text, selecting "Format" f"om the upper menu bar, selecting "Character" from the options list, selecting "Red" from the color-options bor, then "Applying" the change to the "Current Characters." After the workbook is completed, discard portions of this overall report package not included in the workbook and delete the instructions provided in the brackets [like this]. To format the completed QA Pli $\eta$ as an open-file report, Districts are required to prepare a cover, title page, and include the Department of the Interior seal. Place this disclaimer on the back of the title page: The use of brand names in this repott is for identification purposes only and does not imply endorsement by the U.S. Geological Survey or the [state the name] District. 


\section{SURFACE WATER QUALITY-ASSURANCE PLAN FOR THE DISTRICT OF}

\section{THE U.S. GEOLOGICAL SURVEY}




\section{CONTENTS}

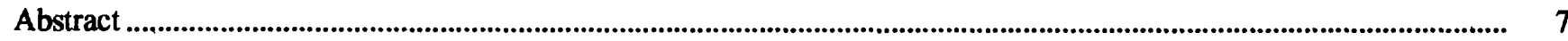

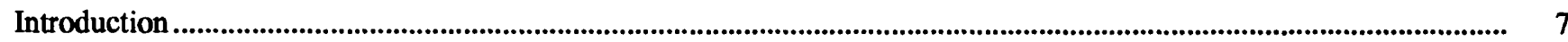

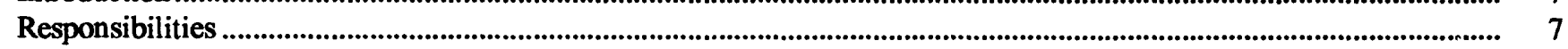

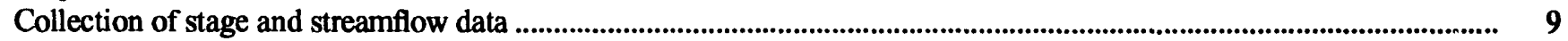

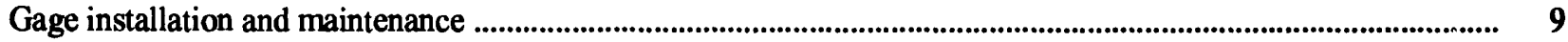

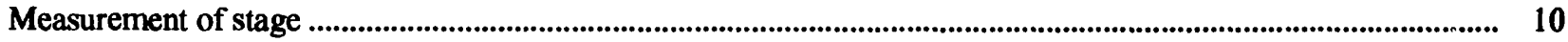

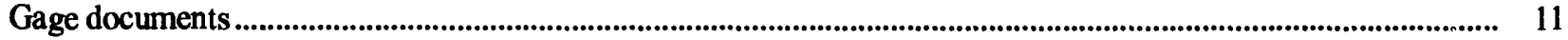

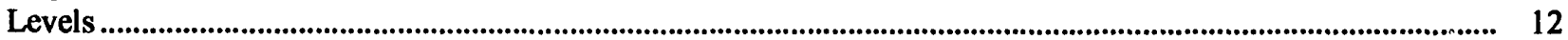

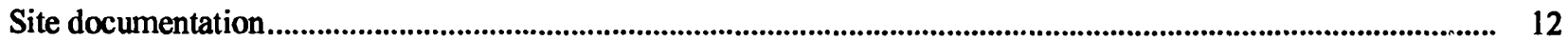

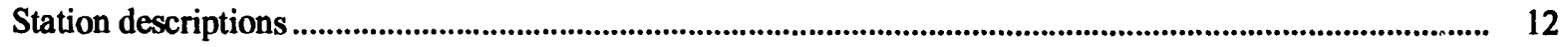

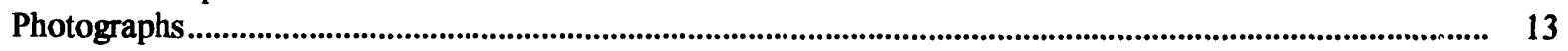

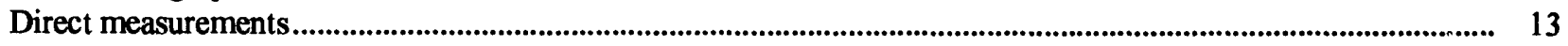

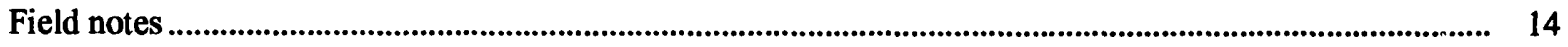

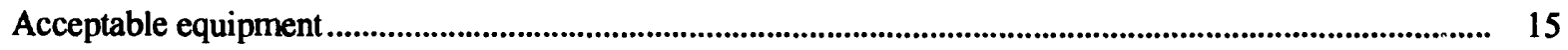

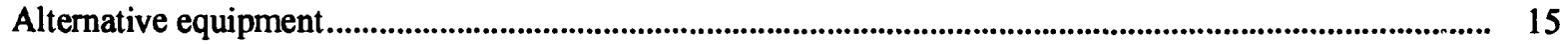

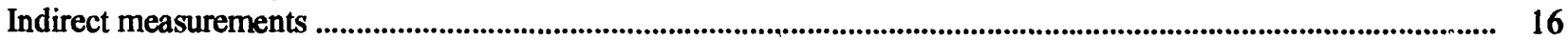

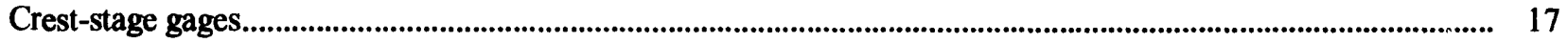

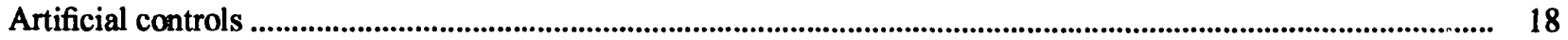

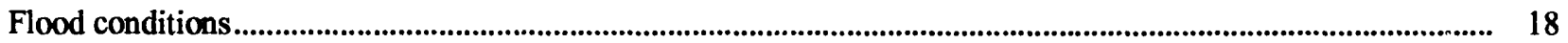

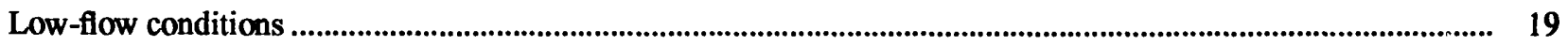

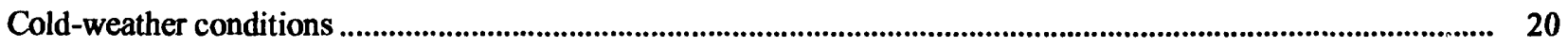

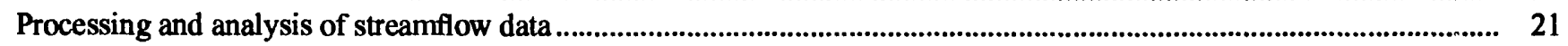

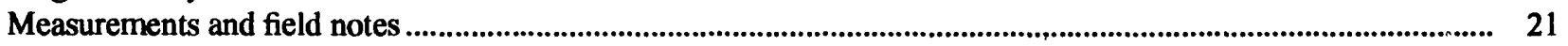

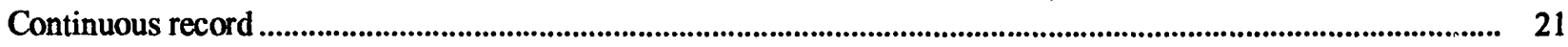

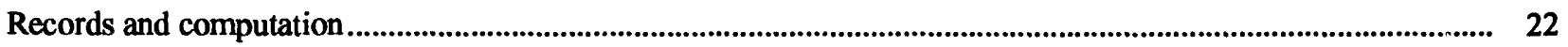

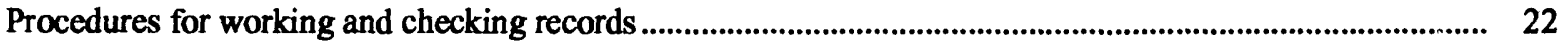

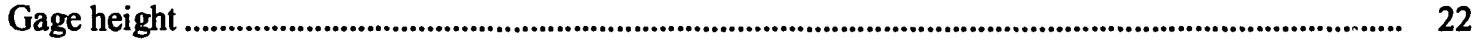

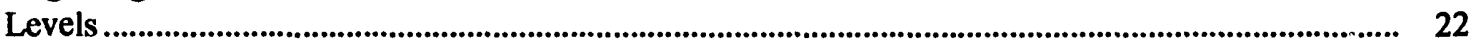

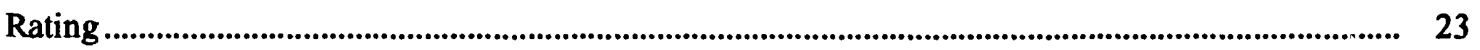

Datum corrections, gage-height corrections, and shifts .................................................................... 23

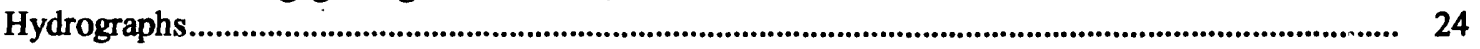

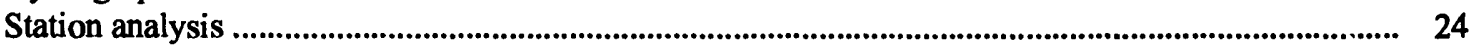

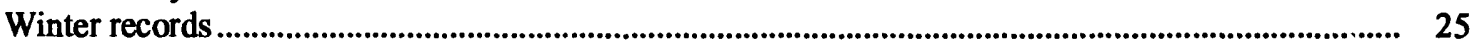

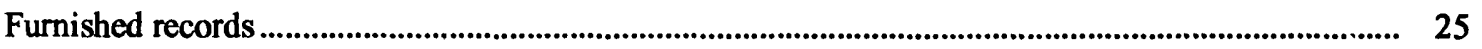

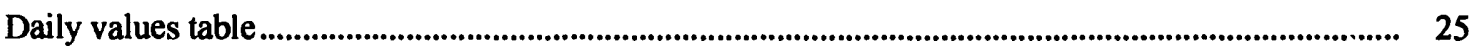

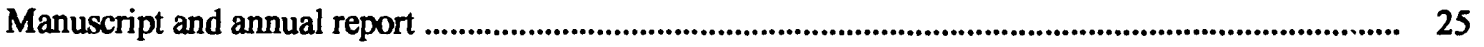

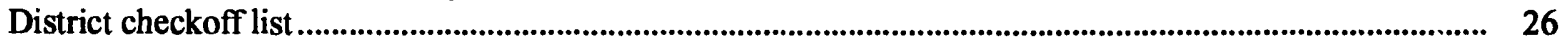

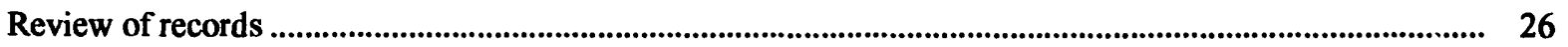

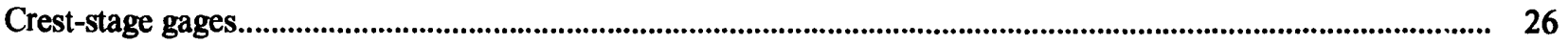

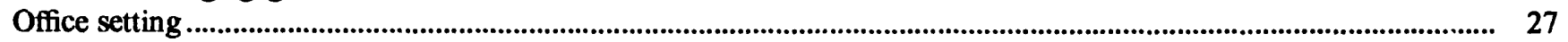

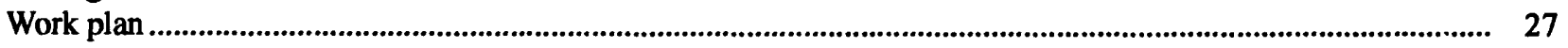

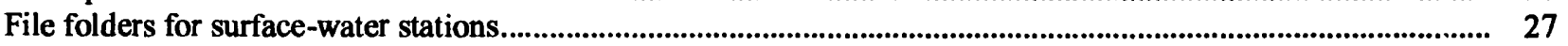

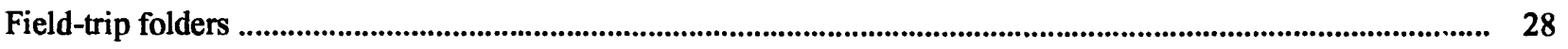

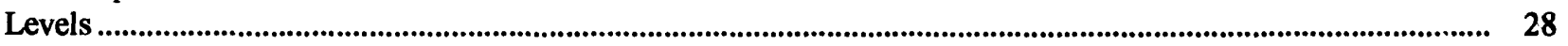

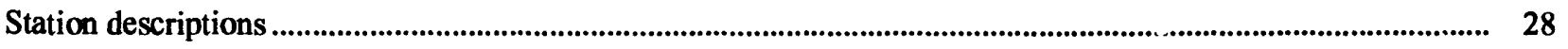

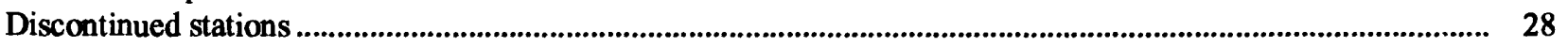

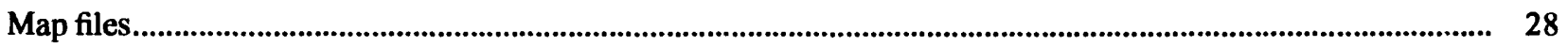

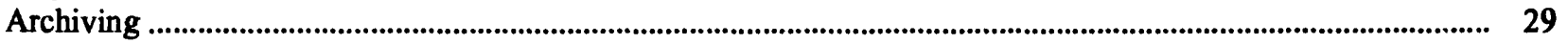

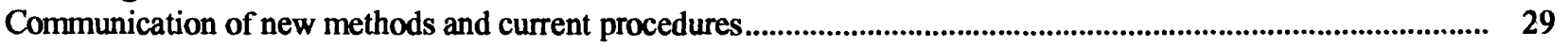




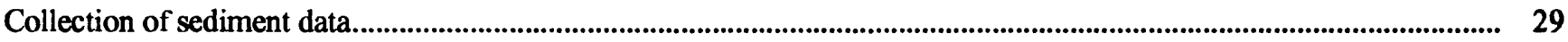

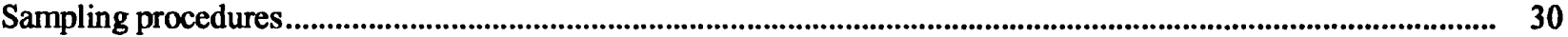

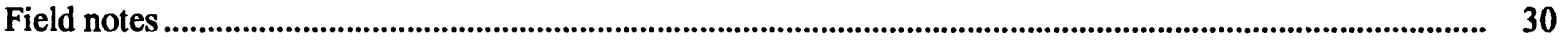

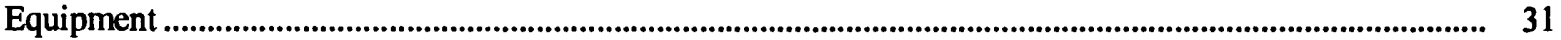

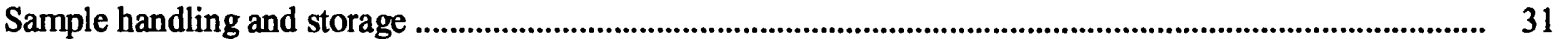

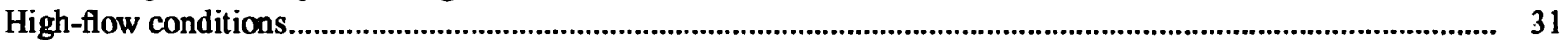

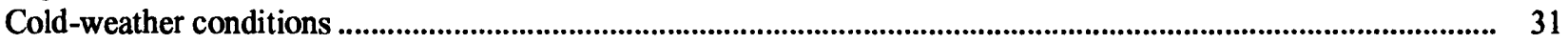

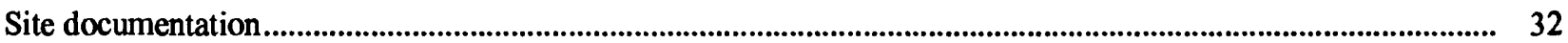

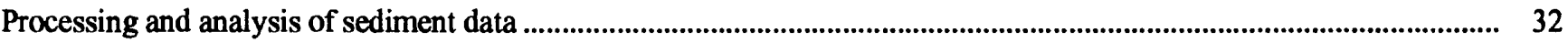

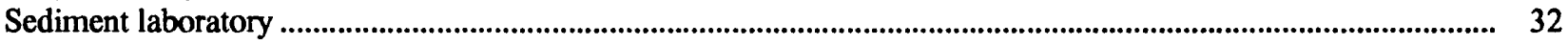

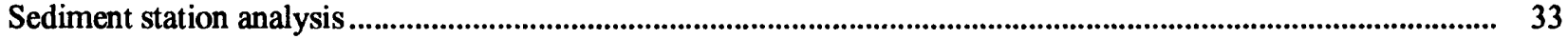

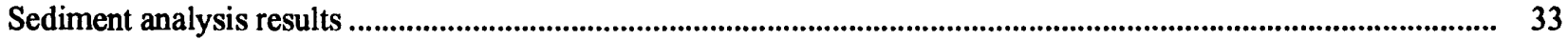

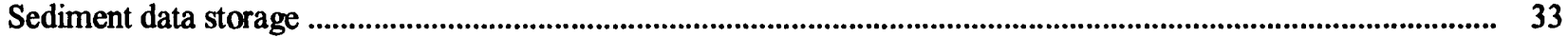

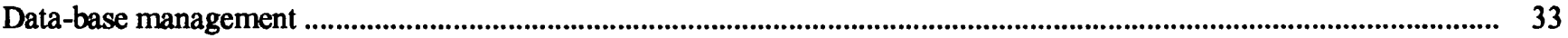

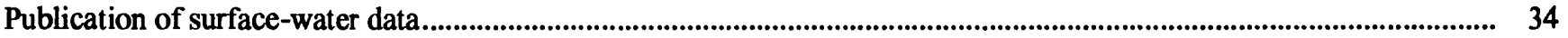

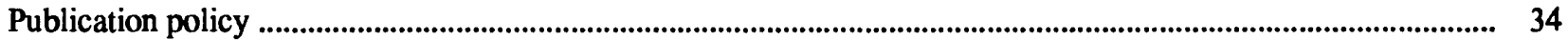

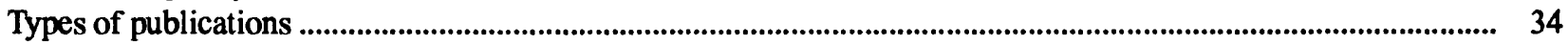

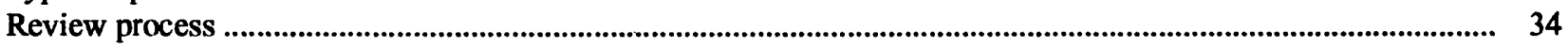

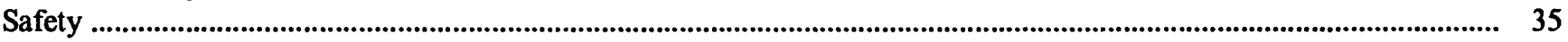

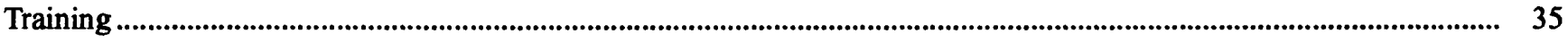

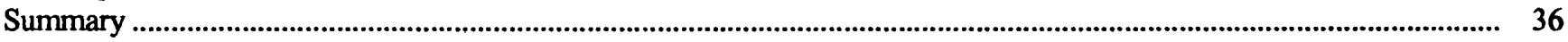

References cited

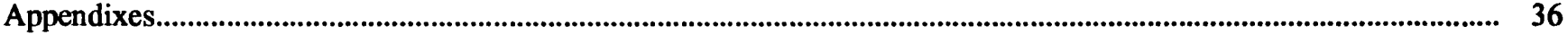

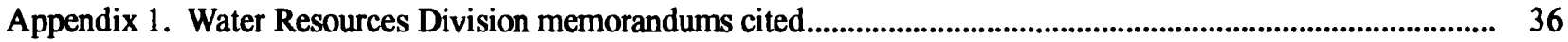

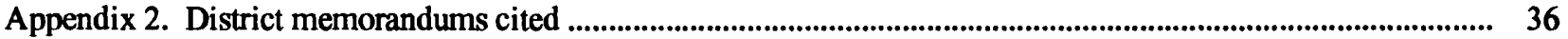

\section{FIGURE}

1. Organizational chart of the Water Resources Division of the U.S. Geological Survey, 1993.............................. 8 


\section{District Surface Water Quality-Assurance Plan Workbook}

\section{Abstract}

This District Surface Water QualityAssurance Plan documents the standards, policies, and procedures used by the [state the name] District for activities related to the collection, processing, storage, analysis, and publication of surface-water data.

\section{INTRODUCTION}

The U.S. Geological Survey (USGS) was established by an act of Congress on March 3,1879, to provide a permanent Federal agency to perform the systematic and scientific "classification of the public lands, and examination of the geologic structure, mineral resources, and products of the national domain." Surface-water activities in the [state the name] District are part of the Water Resources Division's (WRD) (fig. 1) overall mission of appraising the Nation's water resources. Surface-water information, including streamflow, stage, and sediment data, are used at the Federal, State, and local levels for resources planning and management.

The purpose of this District Surface Water Quality-Assurance Plan (QA Plan) is to document the standards, policies, and procedures used by the [state the name] District for activities related to the collection, processing, storage, analysis, and publication of surface-water data.

This plan identifies responsibilities for ensuring that stated policies and procedures are carried out. The plan also serves as a guide for all District personnel involved in surface-water activities and as a resource for identifying memorandums, publications, and other literature that describe in more detail associated techniques and requirements.

The scope of this report includes discussions of the policies and procedures followed by this District for the collection, processing, analysis, storage, and publication of surface-water data. Specific types of surface-water data include stage, streamflow, sediment, and basin characteristics. In addition, issues related to the management of the computer data base and employee safety and training are presented. Although procedures and products of interpretive projects are subject to the criteria presented in this report, specific interpretive projects are required to have a separate and complete quality-assurance plan.
This QA Plan is reviewed and revised at last once every 3 years in order that responsibilities and methodologies are kept current, and that the ongoing procedural improvements can be effectively documented.

\section{RESPONSIBILITIES}

Quality assurance (QA) is an active process. Achieving and maintaining high-quality standards for surface-water data are accomplished by specific actions carried out by specific persons. Errors and def $:$ iencies can result when individuals fail to carry out their responsibilities. Clear and specific statements of resfonsibilities promote an understanding of each person's duties in the overall process of ensuring surface-water data quality.

[This section of the QA Plan is designed to be a detailed and comprehensive summary of responsibilities related to the quality assurance of surface-water data. Responsibilities are assigned to personnel by position title, not by personnel's names. The responsibility for the preparation of, implementation of, and adhrence to the $Q A$ policies described in the QA Plan is with the District Chief (Schroder and Shampine, 1992, p. 7). Any delegations of that responsibility and auth rrity should be stated clearly in the QA Plan. The rosition title of the party responsible for future updates and revisions of the QA Plan should be identified in thic section of the report.]

[Districts may find that the most effective way of writing this section of the report is to prepare a list of all position titles of District personnel associated with surface-water dat a collection, processing, storage, and publication: then list the surface-water-related responsibilities held by that position. As other sections of this workbook are completed and further responsibilities are discussed, the lists of responsibilities can be appended. Finally, when the remaining sections of the workbook have been completed, this "Responsibilities" section can be revisited and finalized. Include chiefs of shortterm projects in the list of position titles and d:fine their responsibility to prepare $Q A$ plans as pa"t of their proposals and work plans (Shampine and others. 1992, p. 2).] 


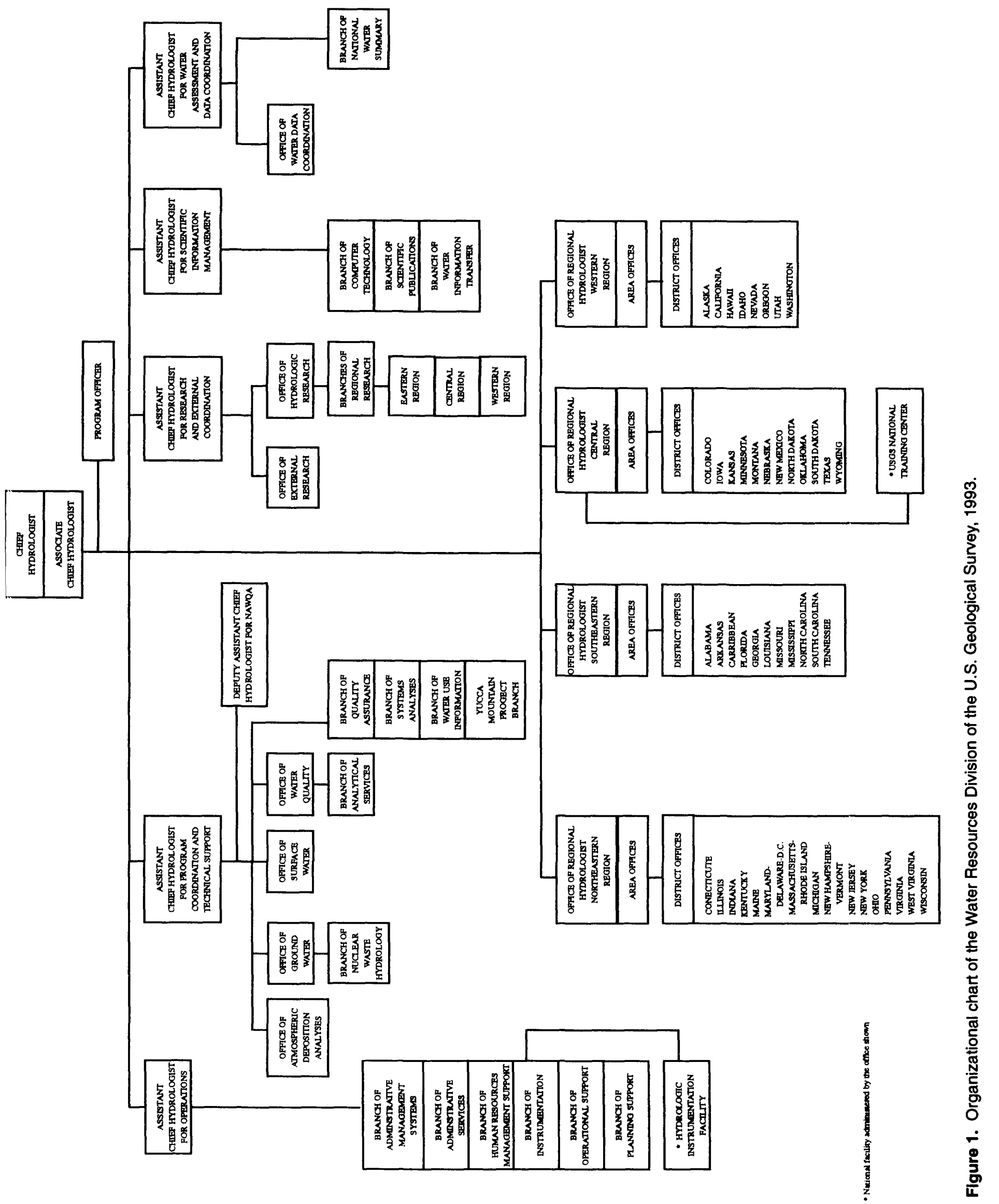

8 A Workbook for Preparing Surface Water Quality-Assurance Plans for Districts of the U.S. Geological Sun'ay, Water Resources Divisioin 
The following is a list of responsibilities of District personnel involved in the collection, processing, storage, analysis, or publication of surface-water data.

The District Chief is responsible for: [The following are a few examples.]

1. Managing and directing the District program, including all surface-water activities.

2. Ensuring that surface-water activities in the District meet the needs of the Federal Government, the [state the name] District, State and local agencies, other cooperating agencies, and the general public.

3. Ensuring that all aspects of this QA Plan are understood and followed by District personnel. This is accomplished by the District Chief's direct involvement or through clearly stated delegation of this responsibility to other personnel in the District.

4. Providing final resolution of any conflicts or disputes related to surface-water activities within the District.

5. Keeping subordinates briefed on procedural and technical communications from Regional offices and headquarters.

6. Performing technical reviews of all surface-water programs on a [select: quarterly, semiannual, or other] basis.

7. Ensuring that all publications and other technical communications released by the District are accurate and are in accord with USGS policy.

\section{8. [Continue to list other responsibilities of the District Chief.]}

[Continue to list position titles and associated responsibilities. Include positions, such as Subdistrict Chief, Field Office Chief, Section Chief, SurfaceWater Specialist, Data Base Administrator. Computer Specialist, project chief, lead technician. temporary aids, Administrative Officer, Safety Officer, senior technician, warehouse manager, vehicle administrator, Sediment Specialist, WaterUse Specialist, sediment laboratory chief, flood coordinator, and others.]

\section{COLLECTION OF STAGE AND STREAMFLOW DATA}

Many of society's daily activities, including industry, agriculture, energy production, wast? disposal, and recreation, are closely linked to straamflow and water availability; therefore, reliable surfa-e-water data are necessary for planning and resource management. The collection of stage and streamflow data is a primary component in the ongoing operation of streamflow-gaging stations (referred to in the remainder of this report as gaging stations) and other waterresource studies performed by the USGS and the [state the name] District.

The objective of operating a gaging station is to obtain a continuous record of stage and discharge at the site (Carter and Davidian, 1968, p. I). A continuous record of stage is obtained by installing instruments that sense and record water-surface elevation in the stream. Discharge measurements are made at periodic intervals to define or verify the stage-discharge relation and to define the time and magnitude of variations in that relation.

It is the policy of this District that [state policy of the District pertaining to the conformance to WRD guidelines on the collection of stage and discharge data, such as all personnel involved in the collection of stage and discharge data are informed of and follow the surface-water data-collection policies and procedures established by the WRD].

\section{Gage Installation and Maintenance}

Proper installation and maintenance of gaging stations are critical activities for ensuring quality in streamflow-data collection and analysis. Effe tive site selection, correct design and construction. and regular maintenance of a gage can make the difference between efficient and accurate determination of drainage-basin discharge or time-consuming, poor estimations of flow.

Sites for installation of gaging stations are selected with the intent to meet the purpose of each specific gage. Additionally, sites are selected with the intent of achieving, to the greatest extent possit' 'e, ideal hydraulic conditions. Criteria that describe th? ideal gaging-station site are listed in Rantz and others (1982, p. 5). These criteria include unchanging natural controls that promote a stable stage-discharge relation, a satisfactory reach for measuring discharge throughout the range of stage, and the means for efficient a ceess to the gage and measuring location. Other aspects of controls considered by District personnel when planning gage-house installations include those discuss $9 \mathrm{~d}$ in Kennedy (1984, p. 2). 
The individual responsible for selecting sites for new gaging stations is [state position of the responsible party (RP), such as Surface-Water Specialist, Subdistrict Chief, or other]. The process of site selection includes [state what steps are taken to select sites, such as discussion with cooperators on the purpose of the gage, analysis of terrain with the use of topographic maps, field reconnaissance, file search to determine if discontinued stations or partial record stations existed in the area, or other]. The responsibility for ensuring proper documentation of agreements with property owners is held by [state position of $R P$ ]. Approval of site design is the responsibility of [state position of $R P$ ]. Responsibility for construction of gages is held by [state position of $R P$ ]. Inspection and approval of the completed installation are the responsibility of [state position of $R P]$.

A program of careful inspection and maintenance of gages and gage houses promotes the collection of reliable and accurate data. Allowing the equipment and structures to fall into disrepair can result in unreliable data and safety problems. It is District policy that a visual inspection is performed at sites by field personnel [select: during each site visit, once each year, or other]. To prevent the buildup of mud or the clogging of intakes, stilling wells are pumped [state the District policy on how frequently wells are pumped and intakes are flushed, such as wells are pumped annually at streamflow-gaging stations and once every 2 years at lake gages, and equipped intakes are flushed during each site visit, or other]. Other maintenance activities performed on a regular basis include [list activities, such as annual oiling of instruments, installation of heat lamps each winter to reduce the effects of cold temperatures, checking battery voltage, or other].

It is the responsibility of [state position of the $R P]$ to ensure that gages and gage houses are kept in good repair. To ensure these responsibilities are carried out, [state how maintenance is reviewed, such as by annual inspections of a percentage of gage houses, or other, and list what aspects are included in the inspections. State how and to whom deficiencies are communicated. Who is responsible for ensuring that deficiencies are remedied?].

[Districts may choose to include other items of policy and procedure related to gage installation and maintenance in this section of the report.]

\section{Measurement of Stage}

Many types of instruments are available for measuring the water level, or stage, at gaging stations. There are nonrecording gages (Rantz and others, 1982, p. 24) and recording gages (Rantz and others, 1982, p. 32). Because the uses to which stage data may be put cannot be predicted, it is OSW policy that surface-water stage records at stream sites be collected with instruments and procedures that provide sufficient accuracy to support computation of discharge from a stage-discharge relation, unless greater accuracy is required (Office of Surface Water Memorandum 93.07).

In general, operation of gaging $s^{\star}$ ations for the purpose of determining daily discharge includes the goal of collecting stage data at the accuracy of \pm 0.01 foot (Office of Surface. Water Memorandum 89.08). [The District may choose to provide situations where lower accuracy is acceptable.] An explanation of WRD policy on stage-measurement accuracy, as it relates to instrumentation, is provided in Office of Surface Water Memorandum 93.07.

The types of instrumentation installed at any specific gage house operated by [state the nome] District is dependent on [state what factors are considered when equipment is installed, such as the need's of the cooperator, the availability of utility lines, terrain, the expected range of stage, or other]. Types of waterlevel recorders operated by personnel in this District include [state the various types of recorders that are used].

The responsibility for determinir. what type of water-level recorders are operated at e $\mathrm{c}$ h gaging station is held by [state position of RP. Ti o District may choose to expand on aspects, such as when 15-minute stage recorders are installed rather than 60-minute or 24-hour recorders, or when pressure-sensor recorders are installed rather than float-type recorders, and other]. Ensuring that new equipment has been installed correctly is the responsibility of [state position of RP. It may be appropriate to state if responsibilities are assigned differently for different types of equipment]. Proper maintenance of gage instrumentation or replacement, if appropriate, of equipment is the responsibility of [state position of RP, such as field personnel who service the gage].

Accurate stage measurement requires not only accurate instrumentation but also proper installation and continual monitoring of all system components to ensure the accuracy does not deteriorate with time (Office of Surface Water Memorandum 93.07). To ensure that instruments, located within the gage house, 
record water levels that accurately represent the water levels of the body of water being investigated, "inside" and "outside" water-level readings are obtained by independent means. For example, [state a representative example, such as, at a given stilling-well gaging station, all recording gages are calibrated to an electric-lape gage located on the recorder shelf, and outside readings are made with a wire-weight gage mounted on a bridge rail near the gage house]. The inside gage readings do not necessarily always equal outside readings, especially if the gages are not in the same pool at all ranges of stage. At stations equipped with a stilling well, the base or reference gage usually is an instrument installed inside the gage house, and other gages are installed outside the gage house to indicate whether or not the intakes are operating properly (Rantz and others, 1982, pp. 53 and 64). [Districts should amend this statement to best explain the local conditions.]

Personnel servicing the gage are responsible for comparing inside and outside readings during each site visit to determine if the outside water level is being represented correctly by the gages. If a deficiency is identified, personnel servicing the gage are responsible for thoroughly documenting the problem on the field note sheet and either correcting the problem immediately or contacting [state position of RP] so that corrective actions can be taken at the earliest opportunity.

Ensuring that instrumentation installed at gaging stations is properly serviced and calibrated is the responsibility of [state position of RP, such as lead technicians, Surface-Water Specialist, Subdistrict Chief, or other]. This responsibility is accomplished by [state how inconsistencies are identified, how excessive periods of incorrect gage height are identified, and other]. When deficiencies are identified, [state what is done to correct the problem, such as requiring field personnel to carry extra replacement equipment, providing further instruction for proper calibration procedures, or other. Identify who is responsible for carrying out the corrective actions]. Individuals who have questions related to the calibration and maintenance of water-level recorders should contact [state position of $R P$ for providing answers to such questions].

[The District may choose to include specific statements on policy and procedures related to instrumentation. Are there standard procedures for documenting gage height at bubble gages or for applying corrections for errors caused by temperature variations (Office of Surface Water Memorandum 91.09)? Are there standard policies on how far recorders can deviate from base gages before they are adjusted to agree with base gage? Are there policies for the use of maximum-stage and minimum-stage indicators? Is the use of pressuresensor-type gages preferred under certain conditions and avoided under other conditions? Are there other policies or procedures that can ultimately affect the quality of the data?]

\section{Gage Documents}

It is District policy that certain documer's are placed in each gage house for the purpose of keeping an onsite record of observations, equipment maintenance, structural maintenance, and other information helpful to field personnel. Documents maintained at each gage house include [the following are examples. Each District should state what information has been found to be most helpful for local conditions: (1) The most recent digital stage-discharge relation (rating); (2) a graph of the rating upon which each new measurement is plotted: (3) the most recent station description listing all gages and reference marks at the site and associated elevations, locations of measurement cross sections, information related to extreme events, including the potential for channel storage between the gage and measuring section during flood conditions, and other information (see the section. "Site Documentation, Station Descrip'ions," in this report): (4) a log updated by field personnel upon each site visit describing control conditions and listing gage readings, measurement values, gagehouse maintenance, and equipment maintenarce: (5) a calendar; and (6) important telephone numbers.]

It is the responsibility of [state position of $R P$, such as personnel who run a field trip regularly, or lead technician, or other] to exchange outdated material with updated gage documents as needed. When field personnel visit a gage house and identify $\varepsilon$ need to update one or more of the documents, [state what field personnel do to remedy the problem, such as fill out a miscellaneous note that is given to the lead technician, keep a log of document needs in a the vehicle or field satchel, or other]. Individuals having question related to what documents should be kept in a gage house, when the documents should be replaced with newer documents, or appropriate methods of append ing logs or plotting measurements, should contact [state position of the RP who can answer such questions]. 
The various gages at a gaging station are set to register the altitude of a water surface above a selected level reference surface called the gage datum. The gage's supporting structures_stilling wells, backings, shelters, bridges, and other structures-tend to settle or rise as a result of earth movement, static or dynamic loads, vibration, or battering by floodwaters and floodborne ice or debris. Vertical movement of a structure makes the attached gages read too high or too low and, if the errors go undetected, may lead to increased uncertainties in streamflow records. Leveling, a procedure by which surveying instruments are used to determine the differences in altitude between points, is used to set the gages and to check them from time to time for vertical movement (Kennedy, 1990, p. 1). Levels are run periodically to all bench marks, reference marks, reference points, and gages at each station for the purpose of determining if any datum changes have occurred (Rantz and others, 1982, p. 545).

It is District policy that levels are run at newly installed gaging stations [state when levels are first run, such as during the first water year that the gage is constructed, at the time of construction, within 6 weeks of when record collection begins, or other]. Levels are run to established gaging stations [describe the criteria on how often levels are run to gaging stations. Districts may find it helpful to refer to Kennedy (1990, p. 14) and Office of Surface Water Memorandum 90.10]. Gages are reset to agree with levels when [state when gages are reset, such as when the levels indicate a 0.015-foot vertical change, or other. Are level notes checked before the reset is made? Are there different criteria for some stations than there are for others?]. When gages are reset, field personnel document the reset by [state on what field notes the documentation is made, such as on a miscellaneous note sheet, on the level note sheet, or other]. [State the District policy on when outside watersurface elevations are required. Additionally, state if an associated time notation is required with selected types of level data. State the type(s) of level instrument used. State other policies associated with levels.]

Levels are run by use of field methods and documentation methods described in Kennedy (1990). Level procedures followed by District personnel pertaining to circuit closure, instrument reset, and repeated use of turning points are described in Kennedy (1990) and in Office of Surface Water Memorandum 93.12. The level instruments are kept in proper adjustment by [describe what methods are used, such as the peg test described in Kennedy (1990, p. 13). Describe how documentation for tests and adjustments are maintained].
It is the responsibility of [state position of $R P]$ to ensure that [all or other] field level notes are checked. The level information is entered in the level-summary form by [state who is responsible for entering the information and when the information should be entered]. Ensuring that levels are run correctly and that all level notes are completed correctly are the responsibility of [state position of $R P$ ]. Ensuring that levels are run at the appropriate frequency is the responsibility of [state the position of the RP].

\section{Site Documentation}

Thorough documentation of qualitative and quantitative information describing each gaging station is required. This documentation, in the form of a station description and photographs, provides a permanent record of site characteristics, structures, equipment, instrumentation, altitudes, location, and changes in conditions at each site. [Th? District may wish to expand on the reasons and uses for site documentation. Some Districts may wish to state local policy related to more documentation thar the two topics presented in this workbook-station descriptions and photographs.] Information pertaining to where these forms of documentation are maintained' is discussed in the section of this report entitled "Office Setting."

\section{Station Descriptions}

A station description is prepared for each gaging station [list other types of surface-water datacollection sites as appropriate to repre.ent local activities] and becomes part of the permanent record for each station. It is District policy that th station description is written [state when the document is prepared, such as no later than 2 weeks after the station is established, at the time the first year's records are computed, or other]. The responsibility for ensuring that station descriptions are prepared cc rectly and in a timely manner is held by [state position of $R P$. If it is general practice that specified personnel write or update the station descriptions, the District should state that information along with how assistance is provided, when needed, to those individuals]. Station descriptions are updated [select: as needed, once every 3 years, or other policy]. It is the responsibility of [state position of RP] to ensure that station descriptions are updated as described. [Provide a statement describing how, when, and by whom station descriptions are reviewed.] 
Station descriptions are written to include specific types of information in a consistent format (Kennedy, 1983, p. 2). [Describe the format and identify what information is included in each station description. The District may choose to do this by including an example of a well-written station description, or by including (or referring to) an outline and examples such as those found in Kennedy (1983, figs. 1 and 2)]

[The District may choose to describe in further detail how station descriptions are written, when and how the drafts are checked, how specific information included in the descriptions are obtained, and other items considered by the District to be beneficial. Who assigns downstream-order station-identification number? When a station description is written for a new station, are site locations required to be plotted on a particular set of maps, and who is responsible for doing and checking the plots? Are there policies regarding where electronic versions of the station descriptions are maintained, how they are protected, and how they are updated?]

\section{Photographs}

Photographs of [state what things are photographed, such as newly installed gage houses, station controls, reference marks, damaged structures, or other] are made by field personnel for the purpose of documenting gage-house construction, changes in control conditions, or to supplement various forms of written descriptions [state other reasons if appropriate]. [State if it is regular practice for all field personnel to carry cameras, or state how cameras can be obtained.] Each photograph that becomes part of the station record is identified by [state how, such as by writing specific types of information on the back of the photograph with a permanent-ink marker]. Photographs for the current year are placed [where, such as in the primary folder, or other], and older photographs are placed [where, for what purpose?].

[The District may choose to expand on the topic of photographs to include discussions of photographs taken for indirect measurements, stereo photographs, aerial photographs, and other. If standard procedures have been instituted on the use of videotape to document surface-water gaging-station structures, channels or controls, or major events, this is the appropriate section of the QA Plan to discuss the procedures.]

\section{Direct Measurements}

Direct measurements of discharge are mate with any one of a number of methods approved by the WRD. The most common is the current-meter method.

A current-meter measurement is the summation of the products of the subsection areas of the stream cross section and their respective average velocities (Rantz and others, 1982, p. 80). Procedures used for current-meter measurements are described in Rantz and others, 1982, p. 139; Carter and Davidian, 1968, p. 7; and Buchanan and Somers, 1969, p. 1.

When personnel make measurements of stream discharge, attempts are made to minimize error: Sources of errors are identified in Sauer and Meyer, 1992. These include random errors, such as depth errors associated with soft, uneven, or mobile streambeds, or uncertainties in mean velocity associated with vertical-velocity distribution errors and pulsatic $n$ errors. These errors also include systematic errors, or bias, associated with improperly calibrated equipment or the improper use of such equipment. [Descrit? what steps are taken to minimize systematic errors. For example, state if field trips are rotated to different personnel every 3 years or so, or, if annually, each field trip is performed by someone other than the one who usually performs the trip.]

District policies related to the measurement of discharge by use of the current-meter method, in accordance with WRD policies, include the follcwing. [Districts are encouraged to modify or expand the following policies to appropriately address local conditions.]

Depth criteria for meter selection.-District personnel select the type of current meter to be used for each discharge measurement on the basis of criteria provided by the OSW (E. Hubbard, written conmun., 1995). Meters are used with caution when a measurement must be made in conditions outside of the ranges of the method provided by the OSW. Any devintion from these criteria are noted, and the measurement accuracy is downgraded accordingly.

[Districts are encouraged to list specific information on the recommended depth and velocity ranges for use of the pygmy current meter or the AA moter. This can be done by presenting excerpts from the written communication mentioned in the preceding paragraph, presenting the tables included in that communication, or describing the criteria in a manner the District believes is most effective for the local situation.] 
It is recommended that a change of meters is not made during a measurement in response to the occurrence of two or more subsections in a single measurement cross section that exceeds the stated ranges of depth and velocity. [Districts may choose to mention situations when a change of meters is recommended or allowed during a measurement, for example, when a very shallow overflow or secondary channel is to be measured along with a larger, deeper main channel.]

Number of measurement subsections.-The spacing of observation verticals in the measurement section can affect the accuracy of the measurement (Rantz and others, 1982, p. 179). The WRD criteria are that observations of depth and velocity be made at a minimum of about 30 verticals, which are normally necessary so that no more than 5 percent of the total flow is measured in any 1 vertical. Even under the worst conditions, the discharge computed for each vertical should not exceed 10 percent of the total discharge and ideally not exceed more than 5 percent (Rantz and others, 1982, p. 140). Exceptions to this policy are allowed in circumstances where accuracy would be sacrificed if this number of verticals were maintained, such as for measurements during rapidly changing stage (Rantz and others, 1982, p. 174). Fewer verticals than are ideal are sometimes used for very narrow streams (about 12 feet wide when an AA meter is used and about 5 feet wide when a pygmy meter is used). Measurement of discharge is essentially a sampling process, and the accuracy of sampling results typically decreases markedly when the number of samples is less than about 25 .

Other direct methods of measuring discharge.It is District policy that WRD and OSW techniques and guidelines are followed when discharge measurements are made with any selected method of measurement. These methods include [indicate what other methods are used in District operations. These methods might include the moving-boat method, the tracer-dilution method, measurements using float or volumetric techniques, and methods involving portable weirs and flumes. Districts may find it helpful to reference Rantz and others (1982), Buchanan and Somers (1969), and Kilpatrick and Schneider (1983)].

Computation of mean gage height.-District personnel use procedures for the computation of mean gage height during a discharge measurement presented in Rantz and others (1982, p. 170). Mean gage height is one of the coordinates used in describing the stagedischarge relation at a streamflow-gaging site.
Check measurements.-A secord discharge measurement is made for the purpose of checking a first-discharge measurement when [state what criteria are used for determining when a check measurement should be made. Additionally, state what steps should be taken when a check measurement is made, such as moving to a new measurement section for wading measurements, with new verticals for measurements from a bridge, or other. Districts may choose to reference Rantz and others (1982, p. 346)].

Corrections for storage. - Corrections for storage applied to measured discharges for the purpose of defining stage-discharge relations are those discussed in Rantz and others, 1982, p. 177, and in Office of Surface Water Memorandum 92.09.

Questions.-Personnel who have questions concerning the appropriate procedures for making stage and discharge measurements should ad tress their questions to [state position of $(R P)]$.

\section{Field Notes}

Thorough documentation of field observations and data-collection activities performe 1 by field personnel is a necessary component of surface-water data collection and analysis. To ensure that clear, thorough, and systematic notations are made during field observations, discharge measurements are rccorded by field personnel on [state what measurement forms are used, state if and how instrument printouts are used, and other similar guidelines. Districts may find it helpful to reference Buchanan and Somers (1969)]. Original observations, once written on the note sheet, are not erased. Original data are corrected by crossing the value out then writing the correct value. Some examples of original data on a discharge-measurement note sheet include gage readings, depth, [state other information the District considers important to point out]. Examples of information on a discharg--measurement note sheet that is derived from original data, but not in itself original data, include [state examples, such as the total discharge on the front sheet, mean gage height. and other]. Derived data can be erased for the purpose of correction.

It is District policy that all discharge measurements [state policy, such as measurements are calculated in their entirety before field personnel leave the field site, unless emergency evacuation is required for reasons of safety]. Information required to be included by field personnel on the measurement note sheet includes, at minimum, the initials and last name of all field-party members, date, times associated with gage readings, and other observations [state other items required]. 
Notations associated with miscellaneous surface-water data-collection activities are to be documented on the basis of [state policy as to which form is required]. All miscellaneous notes are required to include, at minimum, initials and last name of fieldparty members, date, time associated with observations, purpose of the site visit [list other items as appropriate].

A review of field note sheets is required [state when, such as annually, semiannually, after each trip, annually as part of surface-water records review, or other] by [state position of RP. Some comments related to points checked when discharge records are worked are appropriate]. Deficiencies found in the content, accuracy, clarity, or thoroughness of field notes are identified and communicated to [state position of RP] by [select: written, oral] means. The deficiencies are remedied by providing specific instructions [by whom] to individuals who fail to record notations that meet USGS and District standards.

\section{Acceptable Equipment}

Equipment used by the [state the name] District for the measurement of surface-water discharge has been found acceptable by the WRD through use and testing. An array of acceptable equipment for measuring discharge includes current meters, timers, wading rods, bridge cranes, tag lines, and others (Rantz and others, 1982, p. 82; Smoot and Novak, 1968). Although an official list of acceptable equipment is not available, Buchanan and Somers (1969), Carter and Davidian (1968), and Edwards and Glysson (1988) discuss the equipment used by the USGS.

The meters most commonly used by District personnel for measuring surface-water discharge are the Price AA current meter and the Price pygmy current meter [state other acceptable meters if this sentence does not represent the local practice]. Methods followed by District personnel for inspecting, repairing, and cleaning these meters are described in Smoot and Novak (1968, p. 9), Rantz and others (1982, p. 93), and Buchanan and Somers (1969, p. 7).

The ultimate responsibility for the good condition and accuracy of a current meter rests with field personnel who use it (Office of Surface Water Memorandum 89.07). A timed spin test made a few minutes before a measurement does not ensure that the meter will not become damaged or fouled during the measurement. Field personnel must assess apparent changes in velocity or visually inspect the meter periodically during the measurement to ensure that the meter continues to remain in proper operating condition.
[The following is one example of a possible spintest policy. State procedures adopted by the L:trict that ensure instrument accuracy and best document quality control of instrumentation.]

Spin tests.- It is District policy that spin tests are required prior to each field trip. Spin-test results are documented in a $\log$ [select: that is maintained for each instrument, or that lists all spin tests for all current meters in chronological order, or other. Also state where the log is located in the office]. This log is part of the archived data of the WRD (Office of Surface Water Memorandum 89.07). Repairs are made to meters when deficiencies are identified through the spin test or inspection. Review of this $\log$ by [state RP, such as lead technician] is required [select: monthly, semiannually, annually, or other]. If deficiencies are observed during this review of the log, [state position of $R P$ for remedying the problem] is informed through [select: oral, written] communication and the problem is corrected immediately. [State when and how an overall review is performed, such as by the SurfaceWater Specialist during annual program review, and state how deficiencies are documented and corrected.]

In addition to the timed spin tests performed prior to field trips, field personnel are required to inspect the meter before and after each measurement to see that the meter is in good condition, that the cups spin freely, and the cups do not come to an abrunt stop. Descriptive notations are made at the appropriate location on the field note sheet concerning the meter condition, such as "OK" or "free" or other such comments. To ensure that field personnel carry out their responsibilities in maintaining the equipment they use, the equipment is inspected [by whom and how often. State how deficiencies are documented and who is responsible for ensuring the problems are remedied. How are the corrections documented?]

[In this section of the QA Plan. Districts should state other policies and procedures pertaining to equipment maintenance, what should be done with damaged equipment or worn pivots, and other items.]

\section{Alternative Equipment}

New conditions and the development of new technology sometimes involve the collection of surface-water data with alternative equipment that has not been fully accepted by the WRD. To demonstrate the quality of surface-water data collected with alternative equipment, thorough documentation of prosedures and observations must be maintained. 
Alternative equipment used by this District includes [please list the types of alternative equipment. Explain procedures for comparing results from each piece of alternative equipment against that of acceptable equipment. If no alternative equipment is used by the District, please state that none is used and delete the remainder of this section].

The responsibility for ensuring that alternative equipment is utilized correctly and for ensuring that documentation is comprehensive and is stored correctly is held by [state position of $R P$ ].

[The District may choose to expand on other procedures or policies related to the use of alternative equipment.]

\section{Indirect Measurements}

In many situations, especially during floods, it is impossible or impractical to measure peak discharges by means of a current meter. There may not be sufficient warning for personnel to reach the site to make a direct measurement, or physical access to the site during the event may not be feasible.

A peak discharge determined by indirect methods is in many situations the best available means of defining the upper portions of the stage-discharge relation at a site. Because extrapolation of a stagedischarge relation, or rating, beyond twice the measured discharge at a gaging station is undesirable and may be unreliable, discharge measurements made by indirect methods during periods of high flows are important forms of data (Rantz and others, 1982, p. 334).

The District follows data-collection and computation procedures presented in Benson and Dalrymple (1967). That report includes policies and procedures related to site selection, field survey, identification of high-water marks, the selection of roughness coefficients, computations, and the written summary. The District also follows procedures for measurement of peak discharge by indirect methods presented in Rantz and others (1982, p. 273).

In addition to the general procedures presented in Benson and Dalrymple (1967), the District follows guidelines presented in other reports that describe specific types of indirect measurements suited to specific types of flow conditions. The slope-area method is described in Barnes (1967) and Dalrymple and Benson (1967). The USGS applies the Manning equation in application of the slope-area method. Procedures for selecting the roughness coefficient are described in Arcement and Schneider (1989). The computer-based tool, program C374, available to assist in computations of peak discharge with the slope-area method, is discussed in Office of Surface Water Mer orandum 83.07. Procedures for the determination of peak discharge through culverts, based on a classification system which delineates six types of flow, are described in Bodhaine (1982). The computer-based tool, program A526, available to assist in computations of peak discharge at culverts, is discussed in Offire of Surface Water Memorandum 83.07. At sites v'here openchannel width contractions occur, suct as flow through a bridge structure, peak discharge can be measured with methods described in Matthai (1967) and with the Water-Surface Profile Computation model (WSPRO) (Shearman, 1990). Debris-flow conditions, which are most common in small mountainous tasins, are discussed in Office of Surface Water Memorandum 92.11.

Determinations of water-surface profiles along a stream channel in association with selected discharges are made when studies are performed that involve delineations of flood plains or when evtensions are made to stage-discharge relations at streamflow sites [state additional situations if appropriate]. District personnel are required to follow the procedures associated with step-backwater methods described in Davidian (1984). The computer-based tool used for assisting in the computations of water-surface profiles with step-backwater methods, WSPRO, is discussed in Office of Surface Water Memorandum 87.05.

General guidelines that are follc'ved by the District when making indirect mersurements include those discussed in Office of Surface Water Memorandum 92.10 and in Shearman (1990). Violation of any one of the general guidelines does not necessarily invalidate an indirect measure ment (Office of Surface Water Memorandum 92.10). [State what criteria the District applies to invalidate $a^{n}$ indirect measurement.]

The responsibility for ensuring that indirect measurements are performed correctly' is held by [state position of RP, such as the Surface-Water Specialist, or other]. It is required that a review of procedures and documentation be performed [state when and by whom. State what is included in the review process, how many of the indirect measurements are reviewed, and other aspects of District policy related to indirect-measurement review]. If deficiencies are found during the review, actions taken to remedy the situations include [state who the reviewer is required to notify, how the problems and proposed solutions are communicated. and who is responsible for ensuring that the corrective actions are taken and that the actions actually' correct the deficiencies]. Measurements that are questionable 
and difficult to assess are reviewed by specialists outside the District, and [state position of $R P$ ] is responsible for ensuring that deficiencies identified by the outside party are corrected.

Determining when and where indirect measurements are made is the responsibility of [state position of RP, such as Subdistrict Chief, or other]. For this District, it is a general rule that indirect measurements are made at sites when [state guidelines, such as when peak flow at a site is estimated to be at least twice the discharge of the greatest measured flow, and other criteria].

It is the responsibility of [state position of $R P$ ] to identify and flag high-water marks. Because the quality and clarity of high-water marks are best soon after a flood, personnel traveling in the field are required to have available in their field vehicles [state what marking equipment are kept in the vehicles, such as nails and plastic markers, spray paint, paint sticks, survey flagging, or other]. Because selection of a suitable reach of channel is an extremely important element in making an indirect measurement, at some streamflow-gaging-station sites, the stream reach for indirect measurements at specified ranges of stage has been preselected, and that information has been included in the station description.

After each indirect measurement is computed, the graphs, field notes and data, plotted profiles, maps, calculations or computer output, and written analysis associated with the measurement are checked by [state District policy on how the measurement is checked, and by whom, such as a lead technician, or other]. The information is organized [state how, such as by grouped in a single labeled folder, or other] and is then [state who the information is provided to or where it is filed]. Long-term storage of each indirectmeasurement package includes [state where and how the information is stored].

The responsibility of maintaining the accuracy of the peak-flow data files, including computer data-base files, lies within the District (Office of Surface Water Memorandum 92.10). It is the responsibility of [state position of RP, such as Subdistrict Chief, or other] to ensure that appropriate indirect-measurement results are entered into the peak-flow files. It is the responsibility of [state position of RP] to ensure that the peakflow files are correct. For further discussion on the update and review of the peak-flow files, refer to the "Data-Base Management" section in this QA Plan.

[The District may choose to include other policies related to indirect measurements in this section of the report.]

\section{Crest-Stage Gages}

Crest-stage gages are used as tools throughout the WRD for determining peak stages at otherwise ungaged sites, confirming peak stages at selected sites where recording gages are located, confirming peak stages where manometers or pressure transduc?rs are used, and determining peak stages along selected stream reaches or other locations, such as upstream and downstream from bridges and culverts. The OSW requires quality-assurance procedures comparable to those used at continuous-record stations for the operation of crest-stage gages and for the computation of annual peaks at crest-stage gages (Office of Surface Water Memorandum 88.07).

The operation of crest-stage gages [select: is, is not] part of this District's surface-water progrem. [If "is not" was' selected, delete the remainder of this section from the QA Plan.] Procedures followed by this District in the operation of crest-stage gages are presented in Rantz and others (1982, pp. 9, 77, and 78). One or more gages are maintained at each selected site where peak water-surface elevations are required on a stream. Upstream and downstream gages are maintained at culverts or other structures where watersurface elevations are required to compute flow through the structure and to establish the result ing type of flow.

Except at sites where crest-stage gages a re used only to confirm or determine peak stages. stagedischarge relations are developed in association with the gage based on direct or indirect high-water measurements. Direct or indirect measurements are obtained [state how often, such as yearly, every 2 years, or other] to verify or adjust the rating. Levels are run to the gage [state how often, such as every year, every 3 years, or other] or as soon as possible after significant changes in the gage because of damage to the gage, reconstruction, or other such situation. When extremely high peaks occur, an outside high-u'ater mark to confirm the gage reading is found when possible, is described on the note sheet, and is flagged by a durable indicator so that the elevation of the high-water mark can be determined the next time levels are run.

Field observations are written on [state policy on what note sheets are used]. All field notes are required to include, at minimum, initials and last name of field personnel, date, time of observation [state other items required].

The responsibility for ensuring that corrsct datacollection procedures are used by personnel is held by [state the position of $R P$ ]. This responsibility is carried out by [state how this is done, such as by examining all field note sheets, or by examining all note sheets of per- 
sonnel in their first 3 years of experience, or other method]. When a deficiency in data-collection activities is identified, the problem is remedied by [state how further training is provided and by whom, or other actions taken by the District to correct the problem].

[Districts may choose to expand on policies and procedures related to data collection at crest-stage gages in this section of the report, including such issues as analysis, computation. and documentation of records.]

Policies and procedures for computation of peak discharges at crest-stage gages and associated documentation are presented in this report in the section entitled "Processing and Analysis of Stage and Streamflow Data."

\section{Artificial Controls}

Artificial controls, including broad-crested weirs, thin-plate weirs, and flumes, are built in stream channels for the purpose of simplifying the procedure of obtaining accurate records of discharge (Rantz and others, 1982, p. 12). Such structures serve to stabilize and constrict the channel at a section, reducing the variability of the stage-discharge relation.

Artificial controls [select: are used, are not used] at [select: some, any, or other] gaging stations maintained by this District. In situations where artificial controls are installed as permanent structures, it is District policy that stage-discharge relations are determined by [state policy, such as making currentmeter measurements throughout the range of stage. relying on the design rating when current-meter measurements cannot be made, or other. Districts may find it helpful to refer to Rantz and others $(1982, p .17)$ and Kilpatrick and Schneider (1983, p. 40)]. Portable weir plates and flumes are used by District personnel in situations that include [describe District policy on when these portable devices are encouraged, discouraged, required, forbidden, or other appropriate guidelines]. These portable devices are applied according to methods described in Buchanan and Somers $(1969$, p. 57) and Rantz and others (1982, p. 263).

Ensuring the correct design and installation of artificial controls for this District is the responsibility of [state position of $R P]$. When installing an artificial control, the District personnel take into account the criteria for selecting the various types of controls, principles governing their design, and the attributes considered to be desirable in such structures (Carter and Davidian, 1968, p. 3; Rantz and others, 1982, pp. 15 and 348; Kilpatrick and Schneider, 1983, pp. 2 and 44).

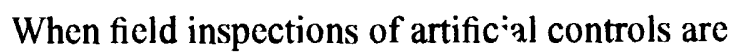
performed, specific information pertaining to control conditions are written on the field note sheets for the purpose of assisting in analysis of the surface-water data. These notes include [state what information is required by the District, such as comments concerning scour or fill of the streambed immediately upstream from the control, or other]. Regular maintenance at artificial controls includes [state District policy on when and how to clean the controls and approach sections, and add some guidance on how the District prefers to document these actions on the fiold note sheet]. When problems pertaining to artificial controls are encountered by field personnel, [state who should be contacted or what the personnel should do in attempting to solve the problems].

\section{Flood Conditions}

Flood conditions present problems that otherwise do not occur on a regular basis. These problems can include difficulties in gaining access to a streamflow gage or measuring site because roads and bridges are flooded, closed, or destroyed. Debris in the streamflow can damage equipment and present dangers to personnel collecting the data. Rapidly changing stage or conditions requiring measurements to be made at locations some distance away from the gage can create problems in associating a gage height to a measured discharge.

The District maintains a flood plan so that highpriority surface-water data associated rith flood conditions are collected correctly and in a timely manner. The flood plan describes responsibilities before, during, and after a flood, informational-renorting procedures, and field-activity priorities. The flood plan serves as a central reference for emergency communications, telephone numbers for key District personnel, and codes for accessing streamflow gares equipped with telemetry. [State other items the District includes in the flood plan.]

It is the responsibility of [state position of $R P$ ] for ensuring that the flood plan include? all appropriate information, including updated information. The flood plan is reviewed [state how ofter the plan is reviewed, such as annually, every 2 years, or other] by [state position of RP, such as District Surface-Water Specialist, Subdistrict Chief, or other]. A copy of the flood plan is provided to [state who receives a copy of the plan, such as all personnel, or other]. Each individual that receives a copy of the plan keeps it [state where the plan is kept, such as near their desk, in their 
field truck, in their field satchel, or other]. It is the responsibility of [state position of $R P$ ] to ensure that individuals that receive a copy of the plan are fully versed on the content of the flood plan.

During a flood, coordination of flood activities is performed by [state if there is such a position as Flood Coordinator, and state the position of the individual who serves as coordinator. If there is more than one office or suboffice, clearly delineate this responsibility in all locations]. For personnel that are not already in the field, their first responsibility during flood conditions is to [state what is expected, such as call the Flood Coordinator before driving to the office, drive to the office with bags packed, or other, or describe how each individual is informed of their first responsibility if global statements are not appropriate]. For personnel that are already in the field, their first responsibility during flood conditions is to [state responsibility, such as proceed to make measurement at first streamflow site, then call Flood Coordinator: immediately call Flood Coordinator; or other]. Personnel who arrive at a gaging station to find that a flood has occurred are responsible for [state responsibility, such as immediately calling the Flood Coordinator if a phone is within 15 minutes of the station; or making a discharge measurement, then proceeding to find and document highwater marks before calling Flood Coordinator; or other]. The District personnel apply methods discussed in Rantz and others (1982, p. 60) for determining peak stage at gaging stations.

District personnel follow policies and procedures stated in a number of publications and memorandums when collecting surface-water data during floods. Techniques for current-meter measurements of flood flow are presented in Rantz and others (1982, p. 159-170). Procedures for identifying high-water marks for indirect discharge measurements are presented in Benson and Dalrymple (1967, p. 11). Adjustments applied to make measured flow hydraulically comparable with recorded gage height when discharge measurements are made a distance from the gaging station are presented in Office of Surface Water Memorandum 92.09 and in Buchanan and Somers $(1969$, p. 54). It is the responsibility of all personnel with questions about particular policies or procedures related to flood activities, or who recognize their need for further training in any aspect of flood-data collection, to address their questions to [state position of $R P$ ].

Review of District activities related to floods is the responsibility of [state position of $R P$ ]. This review includes seeing that guidelines and priorities spelled out in the flood plan are followed and that the guidelines appropriately address District requirements for obtaining flood data in a safe and thorough manner.
When deficiencies are identified by the reviewer, deficiencies are remedied by [state if oral or written communication is provided to the $R P$, state who the $R P$ is, and what is expected from the RP to correct the problem].

[Other District policies or procedures related to flood conditions should be placed in this section of the report.]

\section{Low-Flow Conditions}

Streamflow conditions encountered by $L$; personnel during periods of low flow are typically quite different from those encountered during periods of medium and high flow. Low-flow discharge measurements are made to define or confirm the lower portions of stage-discharge relations for gaging stations. as part of seepage runs to identify channel gains or losses, and to help in the interpretation of other associated data. Additionally, low-flow measurements ar? made to define the relation between low-flow charac + ristics in one basin and those of a nearby basin for which more data are available (Office of Surface Water Memorandum 85.17). [The District may choo'e to list other situations for which low-flow measurements are included in surface-water operations.]

In many situations, low flows are associated with factors that reduce the accuracy of discharge measurements. These factors include algae growth that impedes the free movement of current-meter buckets and larger percentages of the flow moving in the narrow spaces between cobbles. When natural conditions are in the range considered by the field personrel to be undependable, the cross section is physically iniproved for measurement by removal of debris or large cobbles, construction of dikes to reduce the amount of ronflowing water, or other such efforts (Buchanan and Somers, 1969, p. 39). After modification of the cross saction, the flow is allowed to stabilize before the discl arge measurement is initiated. [State other factors associated with channel modifications and what is expected of personnel. What if the modification affects the stage at the gage? Are notes to be made on the note sheet only or also on the digital recorder tape or stripchart?]

District policy requires that point-of-zer)-flow measurements be made by field personnel [state District policy, such as for all wading measurements, for all stations noted on a specified list, or othor].

[If there is a District policy that encourcres or discourages the cleaning of controls during lo"-flow periods, discuss these issues.] 
The individual responsible for ensuring that District personnel use appropriate equipment and procedures during periods of low flow is [state position of $R P]$. Determination that appropriate procedures are used for data-collection activities during low-flow conditions is accomplished by [state how and when the activities are reviewed, such as when surface-water records are reviewed by the Surface-Water Specialist. by biannual review of low-flow activities, by an immediate review of all drought-related data by the Subdistrict Chief, or other]. [State position of RP] is responsible for providing answers to questions from District personnel pertaining to data collection during periods of low flow.

[The District may choose to include other information related to low flow in this section of the report.]

\section{Cold-Weather Conditions}

Surface-water activities in this District [select: include, does not include] making streamflowdischarge measurements during cold weather conditions. [If "does not include" was selected, delete the remainder of this subsection relating to winter conditions.] Cold temperatures, wind, snow, and ice can create difficulties in collecting data. These factors also can create dangers to field personnel. The highest priority in collecting streamflow data during winter periods is employee safety.

For gaging stations where the stream is subject to freezing during the winter, discharge measurements under ice cover and during periods of partial ice cover are useful for analysis and determination of flow throughout winter periods. District personnel are required to follow procedures for discharge measurements under ice cover presented in Buchanan and Somers $(1969$, p. 42). This same publication includes procedures for discharge measurements made by wading or discharge measurements from cableways and bridges when debris and ice are in the streamflow. District personnel also follow procedures to collect winter streamflow data as presented in Rantz and others (1982, p. 124). Additionally, guidelines on equipment for measurement of flow under ice is provided in Office of Surface Water Memorandum 84.05.
Presently, the OSW views the preferred metering equipment for discharge measurements for slush-free conditions under ice cover to be a type AA current meter built with a Water Survey of Canada (WSC) winter-style yoke with a conventional retal-cup rotor. For conditions where slush ice is present, the OSW views the preferred metering equipment to be the WSC winter-style yoke with a polyme- rotor (Office of Surface Water Memorandum 88.18). Although polymer rotors are not allowed (Office of Surface Water Memorandum 90.01) during all other conditions, the superior ability of the polymer rotor to shed slush ice and retard freezing in ice-covered streams is considered to be more important than the turbulentflow-related inaccuracies associated with the rotor (Office of Surface Water Memorandun 92.04). The OSW also views the regular AA meters with conventional metal-bucket rotors to be acceptable for use in slush-free conditions if cutting the required larger holes through the ice is feasible (Office of Surface Water Memorandum 92.04).

District policy on the use of metering equipment on ice-covered streams where sluth ice is present is [state District policy on what meters are used]. District policy on the use of metering equipment on ice-covered streams where no slush ice is present is [state District policy on what meters are used]. When the effective depth of water under ice cover is less than [state District policy on depth], a pygmy meter is utilized.

The responsibility for ensuring the correct use of equipment and procedures for surface-water datacollection activities during periods of winter conditions is held by [state position of RP, such as Surface-Water Specialist, Subdistrict Chief, or other]. This is accomplished by [state how the RP ensures the use of appropriate equipment and procedures, such as by reviewing all field notes immediately following winter field trips, reviewing field note sheets when station records are reviewed annually, or other].

[The District may choose to incl:de other policies related to winter conditions, such as acceptable equipment to include in-field vehicles, call-in safety procedures, multiple-member crews for specific weather conditions or sites, winter-equ:ipment-care requirements, or other.] 


\section{PROCESSING AND ANALYSIS OF STREAMFLOW DATA}

The computation of streamflow records involves the analysis of field observations and field measurements, the determination of stage-discharge relations, adjustment and application of these relations, and systematic documentation of the methods and decisions that were applied. Streamflow records are computed and published for each gaging station annually (Rantz and others, 1982, p. 544). [If appropriate, amend this statement to reflect variations in policy for project-related stations, or other variations.]

This section of the QA Plan includes descriptions of procedures and policies pertaining to the processing and analysis of data associated with the computation of streamflow records. The procedures followed by the [state the name] District coincide with those described in Rantz and others (1982) and in Kennedy (1983).

\section{Measurements and Field Notes}

The gage-height information, discharge information, control conditions, and other field observations written by personnel onto the measurement note sheets and other field note sheets form the basis for records computation for each gaging station. Measurements and field notes that contain original data are required to be stored indefinitely (Hubbard, 1992).

Measurements and other field notes for the water year that is currently being computed are filed [state where the note sheets are generally kept, such as in the primary folder, in a special file drawer, or other]. Measurements and notes for previous water years are filed [state where].

It is District policy that [which measurements] are checked [the District may find it helpful to refer to Rantz and others $(1982, p .547)]$. The measurements are checked by reviewing the mathematics and other items listed in Kennedy (1983, p. 7). [The District may choose to list specific procedures and items to be checked in a manner that is most beneficial for the local situation.]

[The District should describe where measurement information is listed. For example, are the measurement data entered into computer files by use of standard USGS software, then a paper printout of that information filed in a particular folder? The focus of this discussion should be on what is expected of individuals computing the records. Districts may find it helpful to reference Kennedy (1983, p. 12).]

\section{Continuous Record}

Surface-water gage-height data are collected as continuous record (hourly, 15-minute, or 5-minute values, for example) in the form of [list by what means data are recorded, such as by punches on paper tape, pen traces on graph paper, electronic transmissions by satellite, and other]. Streamflow records are computed by converting gage-height record to discharge record through application of stage-discharge relations. Ensuring the accuracy of gage-height record i therefore, a necessary component of ensuring the a curacy of computed discharges.

Gage-height record is assembled for the period of analysis in as complete a manner as possible. Periods of inaccurate gage-height data are identified, then corrected (see the section, "Datum corrections. gageheight corrections, and shifts") or deleted, as c ypropriate. [Districts may choose to state what specific factors are involved in determining what data are corrected and what data are deleted.] Items included in the assembly of gage-height record and procedures for processing the data are discussed in Kennedy $\left(19^{\circ} 3\right.$, p. 6$)$ and Rantz and others (1982, pp. 560 and 587).

[In this section of the QA Plan, the District should describe local procedures for ensuring correct entry of stage data into the computer. Are data for field offices entered at the field office or are tapes transferred to another office for processing? What steps are taken to ensure that original data are not lost in the mail? How are observer records stored, and how is observer information used in relation to continuous record? Are periods of missing record or "bad" record replaced with data from backup recorders? If so, what steps are taken to ensure that appropriate and accurate data are inserted for the missing periods? Describe these and similar procedures in a manner that is most beneficial for the local situation; some Districts may choose to list very specific procedures, and others provide only goals and general guidelines. The focus of this section should be on the procedural aspects of data entry. The authority and responsibilities associated with long-term storage of surface-water data and ensuring the integrity of that historical data are discussed in the "Data-Base Management" section of this report.] 


\section{Records and Computation}

[Provide some overview of how records are computed in the District. Are records for each station computed in part by several individuals in assembly-line fashion, or is each station worked as a whole each year by a single individual? Are records for each station checked? When and how are they reviewed? For new stations, when first-year records are worked, who is responsible for setting up the various files? Districts may choose to describe in this section how responsibilities of the individual computing the record are different from those of the checker, and in what situations the individual who worked the record is required to address corrections suggested by the checker. If personnel from subdistrict offices or field offices compute and check records, do procedures vary from one office to the next? Present information in the manner that best applies to each District.]

\section{Procedures for Working and Checking Records}

Procedures for ensuring the thoroughness, consistency, and accuracy of streamflow records are described in this section of the QA Plan. The goals, procedures, and policies presented in this section are grouped in association with the separate components that are included in the records-computation process.

[Districts should consider the descriptions included under the following headings as examples. The statements should be modified or expanded to best describe the local situations.]

\section{Gage height}

The accuracy of surface-water discharge records depends on the accuracy of discharge measurement, the accuracy of rating definition, and the completeness and accuracy of the gage-height record (Office of Surface Water Memorandum 93.07). Computation of streamflow records includes ensuring the accuracy of gageheight record by comparisons of gage-height readings made by use of independent reference gages, comparison of inside and outside gages, examination of highwater marks, comparisons of the redundant recordings of peaks and troughs by use of maximum and minimum indicators, examination of data obtained at crest-stage gages, and confirmation or updating of gage datums by levels.

Records computation includes examination of gage-height record to determine if the record accurately represents the water level of the body of water being monitored. Additionally, it includes identifying periods of time during which inaccuracies have occurred and determining the cause for these inaccuracies. When possible and appropriate, inaccurate gageheight record is corrected. When correntions are not possible, the erroneous gage-height dat ${ }^{`}$ are removed from the set of data used for streamflov' records computation [Districts may choose to amend this statement to reflect local procedures].

[The District should describe any' policies, procedures, or goals pertaining to gage-height record. For example, are all notes and corrections for gageheight record documented by writing on primary sheets or somewhere else, and are certain colors of pencils recommended for different types of primary-sheet corrections? Are primaries that contain what has been determined to be incorrect gage heights kept, or replaced by primaries that were printed after the data were deleted? Are incorrect gage heights removed from computer record, and is the individual who works the record responsible for deleting the data or is the person who checks the record responsible? Are there policies related to replacing data from one source, such as a digital recorder, with data from another source, such as a satellite data-collection platform. How is that data replacement documented?]

\section{Levels}

Errors in gage-height data caused by vertical changes in the gage or gage-supporting structure can be measured by running levels. Gages can be reset or gage readings can be adjusted by applying corrections based on levels (Kennedy, 1983, p. 6).

Procedures for computing record for each station include [state procedures pertaining to levels, such as ensuring that the front sheet has been completed for each set of levels, checking levels, ensuring that the level information was listed in the historical levels summary, ensuring that information was applied appropriately as datum corrections, or other]. The individual computing the record is required to check field notes for indications that the gages were reset correctly by field personnel [state what actions are taken if gages have not been reset to agree with levels. How are field personnel informed if gage settings require a change?]. The individual computing the records makes appropriate adjustments to the gage-height record by applying datum corrections.

[Districts should list other policios and procedures associated with level notes and records computation.] 
The development of the stage-discharge relation, also called the rating, is one of the principal tasks in computing discharge record. The rating is usually the relation between gage height and discharge (simple rating). Ratings for some special sites involve additional factors, such as rate of change in stage or fall in slope reach (complex ratings) (Kennedy, 1983, p. 14).

District personnel follow procedures for the development, modification, and application of ratings that are described in Kennedy (1984). District personnel also follow guidelines pertaining to rating and records computation that are presented in Kennedy (1983, p. 14) and in Rantz and others (1982, chaps. 10-14 and p. 549).

For each gaging station, the most recent digital rating table can be obtained by [state policy on where the digital table is maintained, such as a paper copy in a particular station folder, in an electronic computer file that must be sent to a printer to produce a paper copy, or other]. A graphical plot of the most recent rating can be obtained [state policy on where the plots are maintained, such as paper copies in a particular set of file drawers or file folders, or stored in electronic computer files that must be sent to a plotter to produce a paper copy, or other].

[The District may choose to list other procedures and policies pertaining to ratings and records computation that promote efficiency and accuracy in the development and documentation of ratings. Are there procedures as to when and how ratings are to be checked? Are there guidelines on when to apply shifts (temporary ratings, discussed later in this section) rather than develop a new rating? Which measurements are required to be plotted on graphical rating plots? Are there guidelines for the extension of ratings? Are there guidelines for when new rating numbers must be assigned? Who is responsible for ensuring that ratings are correctly developed. entered into the computer, checked, and stored? When personnel have questions pertaining to ratings, who is responsible for providing answers to their questions? Is there a policy that new ratings are checked before copies of the ratings are sent outside the office?]
A correction applied to gage-height readings to compensate for the effect of settlement or uplift of the gage is usually measured by levels and is callet a "datum correction" (Kennedy, 1983, p. 9). Datum corrections are applied to gage-height record in te $\mathrm{ms}$ of magnitude (in feet) and in terms of when the datum change occurred. In the absence of any evidence indicating exactly when the change occurred, the cl ange is assumed to have occurred gradually from the time the previous levels were run, and the correction is frorated with time (Rantz and others, 1982, p. 545) [thi' statement should be amended as appropriate to conform to local policy]. Datum corrections are applied when the magnitude of the vertical change is [state policy, such as equal to or greater than 0.015 foot, or other].

A correction applied to gage-height readings to compensate for differences between the recording gage and the base gage is called a "gage-height corr sction" (Rantz and others, 1982, p. 563). These correct ions are applied in the same manner as datum correction : by use of the same computer software. Gage-height corrections are applied so the recorded data are made to agree with base-gage data. These corrections are applied when the difference between the recording gage and the base gage is [state policy, such as equal to or greater than 0.02 foot, or other].

A correction applied to the stage-discharge relation, or rating, to compensate for variations in the rating is called a shift. Shifts reflect the fact that stagedischarge relations are not permanent but vary from time to time, either gradually or abruptly, beca'se of changes in the physical features that form the cc ntrol at the gaging station (Rantz and others, 1982, p. 344). Shifts can be applied to vary in magnitude witl time and with stage (Kennedy, 1983, p. 35). [State specific or general guidelines pertaining to shifts. How are shifts documented? Are stage shifts rather than time shifts encouraged or discouraged? Are there general guidelines on how long shifts should be applied rather than developing a new rating? Are there procedures for ensuring that stage shifts perform as expected? Are there procedures for ensuring that transitions fom the use of shifts to the use of new ratings are correct? Are there guidelines that apply if a larger shift can be applied than that which was measured?]

[State how datum corrections, gage-height corrections, and shifis are documented. Are paper copies of calculations, notes, and diagrams maintained with the analysis form? Are there procedures for checking transitions from one water year to the next? State any other general policies or goals pertaining to tr? topic that may be beneficial to the local conditions.] 
A discharge hydrograph is a plot of daily mean discharges versus time. The date is aligned with the horizontal axis, and the discharge is aligned with the logarithmic vertical axis. In the process of computing station records, this hydrograph is a useful tool in identifying periods of erroneous information, such as incorrect shifts or datum corrections. Additionally, hydrographs are helpful when estimating discharges for periods of undefined stage-discharge relation, such as during backwater or ice conditions, and in estimating discharges for periods of missing record.

Information placed on the hydrograph for each station includes [state items to be included on the form, such as station name, station number, water year, date the hydrograph was plotted, drainage area, plot of daily mean discharge data, plots of measurements, indications of datum corrections and shifts, streamflow stations with which the hydrograph was compared, or other. State guidelines for how various items are indicated on the hydrograph. Are ice estimates made in red pencil and other estimates marked in other colors? Are there specific symbols for specific types of estimates, such as " $a$," " $b$," "e," or " $g$ " days? Where are these symbols to be placed? Who checks the hydrograph?].

[Describe the general procedures and goals of hydrographic comparison. Districts may find it helpful to refer to Rantz and others (1982, pp. 572 and 575). Some Districts may choose to discuss downstream analysis as a tool for ensuring the quality of computed discharge record. Where are hydrographs filed during the computation process, and where are they stored when computations for the water year are completed? Who provides guidance when there are questions concerning hydrographs? Who is responsible for ensuring that hydrographs from previous years are properly stored?]

[Because the hydrograph is an important tool in the records-computation process and is an important form of documentation, many Districts have developed very specific policies and procedures associated with the production, use, and storage of hydrographs. Districts should describe any policies or procedures that effectively represent the local methods and goals.]
A complete analysis of data collected, procedures used in processing the data, and th a logic upon which the computations were based is documented for each year of record for each station to provide a basis for review and to serve as a reference in case questions arise about the records at some future date (Rantz and others, 1982, p. 580). Topics discussed in detail in the station analysis include [list items that are included, such as equipment, hydrologic condition, gage-height record, datum corrections, rating, discharge, special computations, remarks, recommendations, or other. Districts may find it helpful to reference Rantz and others (1982, p. 582) and Kennedy (1983, p. 46)]. The station analysis is written by [state who writes the documentation, such as the individual who prepares the final update for the water year, or other. State if the individuals who work portions of the corputations for the year should write sections of the station analysis pertaining to the work they completed].

[Districts vary in their policies and procedures related to preparation of the station analysis. Some Districts require hand-written documents, and others encourage the use of particular computer software. Describe what forms are to be used, where the forms are to be obtained, or if more appropriate, what software is encouraged or allowed to be used when preparing a station analysis. Describe where incomplete station analyses are to be filed during records computation. Additionally, describe when and where station analyses are backfiled when the records have been finalized. Particular focus should be placed on ensuring consistency in the content of station analyses, on ensuring that the checker can readily obtxin and check the document, and on ensuring that the document is properly stored for future reference even during periods of procedural and computer-equipment transitions. Be specific on what other information is filed with the station analyses, such as computer printouts of shifts and datum corrections, graphs of variableshift diagrams, or other.]

[State the responsibilities of the crocker. In what situations is the checker required to discuss changes or corrections with the individual who worked the records? Who holds the responsibility for resolving disputes? Who holds the responsibility for ensuring that station analyses are prepared and stored properly?] 


\section{Winter records}

Computing records that represent winter periods for gaging stations involves procedures that are not applicable to records that represent other times of the year. [Districts that do not have to contend with winter conditions can choose to delete this section of the QA Plan.] The formation of ice in stream channels or on section controls affects the stagedischarge relation by causing backwater; the effect varies with the quantity and nature of the ice, as well as with the discharge (Rantz and others, 1982, p. 360). During some conditions, the recorded gageheight data may be accurate, although the actual stage-discharge relation may be undeterminable and unstable. An example of this condition would be when surface ice forms on the stream, but the stilling well remains unfrozen and the water level in the stilling well represents the backpressure caused by the ice in the channel. During other conditions, the recorded gage-height data are inaccurate, resulting in periods of missing gage-height record. An example of the latter would be when a stilling well or the intakes to the stilling well are frozen.

The individual computing the station record is responsible for identifying ice-affected periods and [state what the individual does to document the situation and to estimate discharge during the period]. The individual also identifies periods of no gageheight record and [state what the individual does to document the situation and to estimate discharge during the period. Are unit values removed from computer files for periods of "bad gage-height record," and if so, who is responsible for deleting the data?]. The individual who checks the winter records is responsible for [describe the role and responsibilities of the checker].

[Describe how ice-affected discharge measurements are utilized when working station records. Describe any other policies or procedures pertaining to winter records that would be beneficial to local conditions. Are there some stations that may be helpful for basin comparisons because the water does not freeze during most winters? Are there general guidelines on the quality of winter records? Are unit-value plots of gage-height record for winter periods used and filed in a particular manner for future reference?]

\section{Furnished records}

Surface-water data collected under the supervision of other agencies, organizations, or institutions [select: are, are not, or other] received by this office. [If not received, delete remainder of this section.] These data are used [state in general what the dxta are used for, such as for publication in the annual data report, for analysis in various ongoing surface-water investigations, or other].

[Describe what procedures are involved in dealing with furnished data. Are the data checked? Who is responsible for checking the data? How are tho data checked? If errors in the data are suspected, is the furnishing agency contacted to determine if an error has been made? Who is responsible for contacting the furnishing agency? Are letters of correspondence and the computer disk or printed copy of the data received from the agency stored in a particular manner in a snecific location for future reference, or is the information kept available for only a limited period of time?]

\section{Daily values table}

With few exceptions, for each gaging station operated by the WRD, a discharge value is dete'mined and stored for each day. The daily values table generated by use of the records-computation softwar? represents what discharge values are stored for each day of the water year.

[Describe how the daily values table is used during records computation to ensure the quality of the data. Is the table used to cross check values written on primaries or plotted on the hydrograph to ensure that proper discharge values have been stored? Is th? table used to check the final manuscript before the data are published? Is a paper copy of the daily values table stored in a particular location or file for future reference, and who is responsible for properly backfiling a copy? Are there set procedures for individuals to document that the daily values have been checked, and is the daily values table included in that process?]

\section{Manuscript and annual report}

When records computation for the water year has been completed, and the data collected and analy'zed by District personnel have been determined to be correct and finalized, the surface-water data for that water year are published along with other data in the District's annual data report. The annual data report is part of the series entitled "U.S. Geological Survey Water-Data Reports." Information presented in the annual data report includes daily discharge values during the year, 
extremes for the year and period of record, and various statistics. Additionally, manuscript station descriptions are presented in the annual data report. Information contained in the manuscript includes physical descriptions of the gage and basin, history of the station and data, and statements of cooperation.

In preparing the annual data report for publication, the District follows the guidelines presented in the report, "WRD Data Reports Preparation Guide," by Charles E. Novak, 1985 edition.

[Describe what policies and procedures are followed to ensure that correct surface-water information is presented in the annual report. At what point in the process is the information checked? How and by whom is the information for each station checked? Who is responsible for ensuring that surface-water information included in the annual report is correct?]

\section{District Checkoff List}

[Offices vary in how a record of progress is maintained on discharge computation for each gaging station. Many offices find it helpful to have a checkoff list for each station for each water year. This checkoff list is a means of tracking the status of records computation for each station and ensuring that errors do not occur by omitting the necessary procedural steps. $A$ description of how a record of progress is maintained for each gaging station should be presented in this section. Districts may choose to list what items are on the local checkoff list, if one is used, or to place a copy of the checkoff list in this QA Plan. State where the checkoff list is filed during the year, and what is done with the completed checkoff list after discharge records for each station have been finalized.]

\section{Review of Records}

After streamflow records for each station have been computed and checked, records for [state how many or what percentage] of the District's gaging stations are reviewed by [state who is responsible for reviewing the records]. The goal of the review is to ensure that proper methods were applied throughout the process of obtaining the surface-water data and computing the record. [The District may choose to include additional goals. List specific items or specific procedures included in the review. Are basin comparisons considered part of this formal review process? State how findings of the review are documented and how that documentation is stored. If deficiencies are identified, who is notified and how is that notification done? Who is responsible for correcting deficiencies, and are these corrections documented in any way? If specific errors are identified, is it required that only these errors be corrected or are there further steps taken to identify potential similar error: in records that were not reviewed? If questions arise concerning the validity of the identified deficiencies, how are these disputes resolved?]

\section{Crest-Stage Gages}

[If there are no crest-stage gager operated by the District, delete this section from the QA Plan.] Records for crest-stage gages are computed with goals and procedures similar to those for othor gaging stations. The field notes are examined for correctness and accuracy. Peak stages recorded by crest-stage gages are cross referenced with other availab ${ }^{1 e}$ information; the dates of the peaks are determined $t *$ analyzing available precipitation data and peak data from recording gages within the same basin or from nearby basins.

A discussion on the policies and procedures used for field aspects of collecting data at crest-stage gages is included in this report in the section. "Collection of Stage and Streamflow Data." The discussion in this section describes the analysis and office documentation of crest-stage data. This section does not pertain to data collected at crest-stage gages installed solely for the purpose of confirming peak stages at sites where manometer or pressure-transducer gag $s$ are used.

At sites where crest-stage gages are used to compute peak discharges, an initial stage-discharge relation, or rating, is developed for the site by direct or indirect high-water measurements. The rating is verified or adjusted on the basis of subsequent direct or indirect high-water measurements.

For each station, a list of all measurements is maintained, and each measurement is assigned a chronological number. For each station, a $\varepsilon^{r a p h i c a l ~ p l o t ~ o f ~}$ the current rating, along with each recent and each notably high stage-discharge measurement, is made readily available to those who check and review the station record by [state how the plot is made available, such as by keeping a current plot in the station folder. or by keeping a computerized version stored and readily produced through some stated computer program or procedure, or other]. Current station descriptions and a summary of levels are maintained [state where the information is kept, and how it is made available to personnel]. A brief station analysis is written each year describing computation of th a annual peak, identifying which rating was used and the type of flow condition, and describing how the dates of the peaks were determined, [and other items the District requires]. 
Responsibility for assigning the personnel for each crest-stage-gage station is [state the position of who is responsible]. Computations are checked by [state how the records are checked, such as by complete recomputation, by examination of specific portions of the computations, or other. State if the checker discusses changes with the individual that computed the records].

Responsibility for ensuring the correct computation of annual peaks at crest-stage gages is held by [state the position of RP]. Review of the crest-stagegage computations is performed by [state by whom. how, and when a review is performed, how many sites are reviewed, and what procedures are used to review the work]. When incorrect actions or procedures are identified during the review, the problems are remedied by [state what actions are taken to correct the problems and who is responsible for carrying out these actions].

Responsibility for updating the Peak-Flow File promptly after peak data have been finalized is held by [state position of RP]. A current listing of annual peaks is maintained in the station folder for review purposes (Office of Surface Water Memorandum 88.07).

[Districts may choose to expand on policies and procedures related to computation of crest-stage-gage records in this section of the report.]

\section{OFFICE SETTING}

Maintaining surface-water data and related information in a systematic and organized manner increases the efficiency and effectiveness of dataanalysis and data-dissemination efforts. Good organization of files reduces the likelihood of misplaced information; misplaced data and field notes can lead to analyses based on inadequate information, with a possible decrease in the quality of analytical results.

This section of the QA Plan includes descriptions of how station folders, reference maps, levels documentation, and other information related to surface-water data are organized and maintained. Additionally, this section provides an overview of how work activities are designed to be carried out within the office setting.

[Districts that have subdistrict offices and field offices may choose to describe each office separately, or use this opportunity to describe global policies that each suboffice is required to follow. Districts may choose to add other items they consider to be beneficial beyond those listed in this workbook, such as benchmark-elevation files, flood-profile files, indirectmeasurement files, and others.]

\section{Work Plan}

[Because the type of work, the amount of work, and the number of personnel vary greatly from one District to another, the manner in which a work plan is prepared also tends to vary. Include in this section, in a general sense, how the total work load is accomplished each year and how personnel's duties are assigned and communicated to them. Some Districts have a structured and formalized work plan, and others have an informal system where duties are assigied verbally throughout the year.]

[Districts are encouraged to write this sestion in a manner that is most effective for their local conditions. Statements should be included describir? the general work load, how work is delegated, who is responsible for delegating these duties, and other pertinent information. It is not suggested, for example, that detailed lists of assignments be included, such as an individual's name followed by a list of 20 stations for which that individual is responsible. Rather, it would be more appropriate to make the genera! statement that individuals are assigned stations for which they are accountable by certain deadlines. If appropriate, the concept of the total work load should also include the time personnel cannot devote to office duties, such as data-collection field trips and construction.]

\section{File Folders for Surface-Water Stations}

This section of the QA Plan describes the location and makeup of hard-copy files associated with surface-water data. Information pertaining to fles maintained in computer storage can be found in the "Data-Base Management" section of this report. [The following paragraphs in this section are preserted as examples. Districts are encouraged to structure this section in the manner that best describes their system.]

For each gaging station, a separate set of file folders is maintained [state if files are organized by station in downstream order, alphabetically, or other. State if these folders are organized as "current files" and as "backfiles, " or other descriptions as ap" ate. State if current files and backfiles are grouped together by station, if they are kept in separate locations, or other]. Extraneous items are removed from the current files [state when, such as at the begirning of each new water year, after records are determined by an RP to be finalized each year, each summer by temporary help, or other. If appropriate, state when backfiles are examined and extraneous items are removed]. 
The set of current files for each station is grouped as follows: [List items as they are identified locally. The following are only examples.]

Primary folders-The primary folders contain [state what items are included, such as primarycomputation printouts and graphed data of stage and discharge, recent measurement field note sheets, or other. State if data are grouped as a separate folder for each water year, and other similar descriptions].

Technical folder-The technical folder contains [state what items are included, such as the most current digital rating, the most current station analysis, the list of discharge measurements, the station description, or other].

[List other information, if appropriate, to explain what is considered to be part of the current file.]

The set of backfiles is grouped for each station as follows: [List files as they are organized locally. There is a section included in this report for discussing what items are archived.]

[The District should explain responsibilities for maintaining files in proper order, what folders can and cannot be removed from the office, and any other policies or procedures that add to the effectiveness of the office environment.]

\section{Field-Trip Folders}

[Many Districts maintain separate folders for each field-trip area or project study area. The primary purpose of these folders is to compile maps, station descriptions, station lists, and other pertinent information, allowing field personnel to run the trips effectively at a moment 's notice and with a minimum of time spent on last-minute preparations. If this office maintains field-trip folders, please describe what items are contained in the folders and who is responsible for updating the folders. If this office does not maintain fieldtrip folders, replace this section of the report with an explanation of how this type of information is compiled and communicated.]

\section{Levels}

[In this section, describe where and how levelnote sheets are filed. Are recent level notes included in current file folders, then later filed in drawers or backfiles? Where is the level summary book located? Are levels listed in the summary by station name in alphabetical order or by station number in downstream order? Are level notes from current stations somehow separated from discontinued stations? What types of level information are allowed to be removed from the office and what types are not?]

\section{Station Descriptions}

[In this section, describe where copies of the surface-water station descriptions are maintained. Is a copy kept in the current file folders $\mathrm{c}^{\mathrm{m}}$ in backfiles? Is there a folder or a set of folders where copies of station descriptions are compiled? Are these folders organized in downstream order, alphabetically, or in some other way? Is there some procedure in place for individuals to make updates on one particular set of copies? Who is responsible for ensurin? that folders or files are updated? Are current station. somehow separated from discontinued stations? Are continuous gaging-station descriptions kept separate from other surface-water sites, such as lakes or partial-record stations?]

\section{Discontinued Stations}

[This section is intended to provide Districts the opportunity to explain how files for discontinued surface-water stations are maintained. Are station descriptions, old analyses, old ratings, and other information maintained at a specific location? Are there procedures personnel should follow in creating special files when stations are discontinued?]

\section{Map Files}

[In this section, describe how man files are organized. What maps and map scales are available? Who is responsible for ensuring that the maps are maintained in good order? Are some maps allowed to be written on and others not? What maps must stay in the office? Where and how can personnel obtain maps that can be used as work maps or maps that can be taken to the field? What procedures are in plaice for replacing maps or updating maps, and who should be contacted in that regard?] 


\section{Archiving}

All WRD personnel are directed to safeguard all original field records containing geologic and hydrogeologic measurements and observations. Selected material not maintained in field offices is placed in archival storage. Detailed information on what records have been removed to archival centers should be retained in the District or project office (Water Resources Division Memorandum 77.83). The types of original data that should be archived include, but are not limited to, recorder charts and tapes, original data and edited data, observer's notes and readings, station descriptions, analyses, and other supporting information (Water Resources Division Memorandum 92.59; Hubbard, 1992, p. 12). At this time, there is an agreement between the WRD and Federal Records Centers (FRC) of the National Archives and Records Administration to archive original-data records (memorandum from the Chief, Branch of Operational Support, May 7, 1993).

Surface-water information is sent to the FRC from the [state the name] District [state how often, such as every year, as needed, or other. If "as needed' is appropriate, explain how and by whom "as needed" is determined]. [State position of RP] is responsible for deciding what information is sent to the FRC, for ensuring that the information is properly packed and logged, and for ascertaining that the information is received by the FRC. Records of exactly what has been archived are maintained [how and where]. Personnel who have questions concerning archiving procedures should address their questions to [state position of RP]. Personnel who receive requests for information that require accessing archived records should [state what the procedure is, such as refer the request to the $R P$. obtain the requested records from archives with assistance from the $R P$, or other].

[An explanation should be presented on what, how, and when surface-water information gathered as part of other investigations should be archived. Are project chiefs responsible for ensuring that appropriate project data are archived, and who ensures that responsibility is carried out? It may be helpful to include some statements on what is not to be archived. Does the District have a memorandum on archiving data?]

\section{Communication of New Methods and C"Irrent Procedures}

[Briefly describe, in general terms, how new, updated, or clarified policies are communicated to personnel involved with surface-water data collection and analysis. Are meetings held for that purpose? Are reports and instructions incorporated into meotings held for other purposes? Are copies of all memorandums from the WRD and OSW given to each employee, or are the major points communicated in some way by section chiefs, followed by posting a single co,y of the memorandum? Is there a forum for personnel to ask questions and discuss procedures? Is it the responsibility of certain individuals to inform others of correct procedures, or is it the responsibility of all personnel to ask questions in order to find out about such things?]

\section{COLLECTION OF SEDIMENT DATA}

Surface-water activities in the District [select: include, do not include] the collection, analys ${ }^{*}$, and publication of sediment data. [If the District is not involved in sediment-related activities, delete the following sections of this QA Plan that pertain to sediment.] The District operates in adherence to rolicies related to sediment set forth by the OSW.

Responsibility for the sediment discipline was transferred from the Office of Water Quality (OWQ) to the OSW in 1985 (Office of Surface Water Memorandum 92.08). The policies and procetures related to sediment followed by the District are described in selected WRD publications and in memorandums issued by the OSW, OWQ, and WRD. Techniques adopted by the USGS and followed by this District are presented in Knott and others (1992). The District also follows procedures presented in th ree publications for the series "Techniques of Water-Resources Investigations of the U.S. Geological Survey" (TWRI):

Book 3, Chapter Cl- "Fluvial Sediment Concepts," by H.P. Guy (1970);

Book 3, Chapter C2__"Field Methods for Measurement of Fluvial Sediment," by H.P. Guy and V.W. Norman (1970); and

Book 3, Chapter C3-“"Computation of FluvialSediment Discharge," by George Porterfield (1972).

Although no additional TWRI chapters have been written to supersede the above-mentioned reports, Open-File Report 86-531, "Field Methods for Measurement of Fluvial Sediment," by T.K. Edwards and G.D. Glysson (1988), essentially replaces book 3, 
chapter C2 (Water Resources Division Memorandum 71.73, Office of Surface Water Memorandum 88.17, and Office of Surface Water Memorandum 93.01).

A summary of memorandums issued since 1971 related to sediment and sediment transport is provided in Office of Surface Water Memorandum 92.08. A summary of documentation that describes instrumentation and field methods for collecting sediment data is provided in Office of Surface Water Memorandum 93.01.

\section{Sampling Procedures}

District personnel collect suspended-sediment data by using sampling methods that include [select from the following and add others if appropriate: the single vertical method, the Equal Discharge Increment (EDI) method, the Equal Width Increment (EWI) method, and the point-sample method]. Automatic pumping-type samplers [select: are, are not] used. [If "are not" was selected, delete the following sentence.] For installation and use of automatic pumping-type samplers, the District follows the criteria described in Edwards and Glysson (1988, p. 32).

[If observers collect sediment data for this office, state the scope of their duties, how training is provided, and how their work is checked. State who is responsible for ensuring the quality of the data collected by the observers.]

Field methods for sediment sampling are documented in Office of Surface Water Memorandum 93.01. Water samples obtained for the analysis of sediment concentration and particle size are not composited (Office of Surface Water Memorandum 93.01 and Office of Water Quality Memorandum 76.17). For samples that are split, the cone splitter is used (Office of Water Quality Memorandum 80.17).

Policy for the collection and publication of bedload data is provided in Office of Surface Water Memorandum 90.08. This memorandum supersedes policy and guidelines provided in previous Office of Water Quality Memorandums 76.04, 77.07, 79.17, and 80.07, as well as Water Resources Division Memorandum 77.60. Among the policies stated in Office of Surface Water Memorandum 90.08, which are followed by the District, is one stating that three crosssectional procedures are used for bedload sampling: the Single Equal Width Increment (SEWI) method, the Multiple Equal Width Increment (MEWI) method, and the Unequal Width Increment (UWI) method. Additionally, it is stated in Office of Surface Water Memorandum 90.08 that it is the responsibility of the field personnel to select the procedure that is optimal for the local condition. Bedload samples in some situations are analyzed individually and in other situations are analyzed as a composite. Until sampling variability for a particular site is understood by those analyzing the data, all samples are required to be analyzed individually.

[Include statements pertaining to specialized local procedures or District memorandums on the subject. Information on sediment data included in the District Flood Plan could be pointed out in this section.]

The individual in the District resnonsible for scheduling sediment-collection activit: ${ }^{\text {s }}$ at specific sites is [state position of RP]. The individual responsible for ensuring that District personnel use correct procedures to collect sediment data is [state position of the $R P]$. This individual establishes whethrr or not correct procedures are being used by [state how the individual checks data-collection procedures, such as by performing a site trip with each person each y:ar, or by discussing procedures and problems at meetings held twice each year, or other. Additionall:, state how deficiencies are documented and corrected]. Answers to questions from District personnel concerning sediment-sampling techniques are prorided by [state position of $R P]$.

\section{Field Notes}

District personnel are required to fill out note sheets each time a site is visited for the purpose of sediment sampling. The employee complates the note sheet in its entirety before leaving the site. Original observations written on the note sheets are not to be erased; data are corrected by crossing out the original observations and writing the correct information near the original value. The goal of placing information on the field note sheet is to describe the equipment and methods used during the site visit, as well as to describe relevant conditions or changes (Office of Surface Water Memorandum 91.15). For each site visit, information included on the note sheet includes, at minimum, [list the mandatory information, such as site identification, field personnel name, date, time, sampling equipment, method, other, or include a copy of the standard note sheet used by the Dirtrict. If the District determines it to be appropriate, they may prefer to cite Office of Surface Water Memorandum 91.15 rather than provide a comprehensive list]. 
Upon completion of each field trip, field notes are placed [state what is done with the note sheets, such as placing them in the site folder in the office, providing them to the supervisor, or other]. Field notes are checked [state District policy on how and when field notes are checked].

\section{Equipment}

Care and maintenance of the sediment-datacollection equipment are the responsibility of [state $R P$, such as the field personnel that use the specific equipment, or other]. Parts replacement and repair of damaged equipment are accomplished by [state repair protocol. For example, the replacement nozzles and seals are obtained from a RP, or damaged equipment is turned over to $R P$ for repair, or other alternatives]. It is the responsibility of [state position of $R P$ ] to ensure that appropriate equipment is used at all sampling sites. Sampling equipment is selected based on the constituents that are being investigated, the type of analyses that are to be performed, and site conditions, including velocity and maximum depth of water. The District follows equipment-design criteria and guidelines referenced in Office of Surface Water Memorandum 93.01.

\section{Sample Handling and Storage}

The quality of sediment data provided by a sediment laboratory is affected by the quality of the samples received from the field (Knott and others, 1992, p. 2). District personnel are required to prepare sample labels, analysis instructions, and sample documentation according to guidelines presented in Knott and others (1992).

Prior to when sample containers are obtained for use on field trips, they are stored [state how and where containers are stored]. During field trips and prior to use, sample containers are stored [state the District's requirements, such as stored in covered crates, sealed in some manner, or other]. Once the containers have been filled with sediment samples, the samples are stored for the remainder of the field trip [state the District's requirements as to how the samples are protected]. After the field trip, samples are [state District policy on how the samples are stored, how and when they are delivered to the laboratory, and other. Districts may find it helpful to reference Knott and others (1992)].

\section{High-Flow Conditions}

High-flow conditions at most streams, unless the streams are subject to the effects of backwater, are associated with high-energy conditions. The sadiment load and particle sizes associated with high flcrs [select: are, are not] significant factors in sediment studies performed by the District. To ensure that field personnel are aware of their responsibilities in obtaining sediment samples at appropriate sites during highflow conditions, [state what actions are taken by the District to achieve this goal, such as by including specific information in field folders and the District Flood Plan, a list of sediment-sampling sites and sampling requirements are provided to all field personnel, or other]. The individual responsible for ensurin? that sediment samples are obtained during opportunities provided by high-flow conditions is [state the position of the RP, such as Flood Coordinator, Subdistrict Chief, lead technician responsible for each aria, project chief, or other]. The individual responsible for ensuring that the proper sampling equipment and methods are used during high-flow conditions is [state position of RP]. [State position of RP] is responsil le for providing answers to District personnel who have questions concerning high-flow sampling equif ment or sampling procedures.

\section{Cold-Weather Conditions}

Sediment-sampling activities in this District [select: include, do not include] obtaining samples during periods of subfreezing temperatures. [If "do not include" was selected, delete the remainder of this subsection pertaining to cold-weather conditions.] During cold-weather conditions, field personnel shoult take every precaution to ensure their personal safety. Additionally, field personnel should attempt to ensure that equipment is not damaged by floating slabs of ice and that nozzles are not clogged with ice crystals.

When floating slabs of ice pose the danger of damaging sampling equipment, such as during spring breakup, field personnel may manage only to obtain surface samples between the floating slabs of ine (Edwards and Glysson, 1988, p. 86). The proc sdure is noted on the field note sheet and sample label. When anchor ice and frazzle ice are present, it may b: necessary to move the sampling equipment quickly through ice crystals to avoid clogging the nozzle. This procedure is also noted on the field note sheets and sample label. 


\section{Site Documentation}

A station description is prepared for each new sediment-sampling site. At sampling sites where streamflow-gaging activities occur, the description of sediment activities is included in the streamflowgaging-station description. A list of elements included in each station description, along with an explanation of what items are included with each element, is presented in the attachment to Office of Surface Water Memorandum 91.15. At sites where sediment samples are collected, but other streamflow data are not collected, the station descriptions are structured similarly to those for streamflow-gaging stations, and contain similar informational items (Kennedy, 1983, p. 2). At sampling sites where gage houses have been installed, station descriptions are kept in the gage house for the purpose of providing field personnel with information pertinent to sediment-sampling procedures for that particular site. Station descriptions are included in the field folder and are maintained in the office files. Each description includes specific information explaining where the site samples are to be taken and what method is to be used.

The responsibility of ensuring that field copies of station descriptions located at gage houses are kept current is held by [state position of RP, such as Subdistrict Chief, section chief, field personnel assigned to regularly run specific field trips, or other]. Station descriptions are kept current by [state how this is accomplished, such as by annual review and updating by the individual that processes the sediment-station data, or other]. Station descriptions are reviewed to ensure that they are current by [state position of RP, such as Surface-Water Specialist, Water-Quality Specialist, Sediment Specialist, or other]. These reviews are made [state how often, such as once each year, once every 3 years, or other]. When a deficiency is identified during the review of station descriptions, the deficiency is corrected by [state who is notified by the reviewer, how the deficiencies are documented, who is responsible for correcting the problem, and how the correction is documented].

At sampling sites with a gage house, a log of sampling activities is kept. [Explain what is included in the log. The District may choose to add additional guidelines pertaining to site documentation in this section of the text.]

\section{PROCESSING AND ANALYSIS OF SEDIMENT DATA}

Sediment and associated streamflow data are compiled to produce sediment records for specific sites. Data processing of periodic measurements consists of four steps: tabulation, evaluation, editing, and verification (Office of Surface Water Memorandum 91.15). The District follo'vs the considerations and guidelines presented in Porterfield (1972), Guy (1969), and Office of Surface Water Memorandum 91.15 in carrying out thes? four steps.

[Provide a general description of $k, w$ and when sediment records are worked. Is there a checklist to ensure that all steps are completed? Are all records checked? How many site records are reviewed? Who performs the review? What is done to correct deficiencies found during the review?]

The responsibility for ensuring that appropriate procedures are correctly applied in processing sediment data is held by [state position of RF]. During the time the sediment data are being processe $t$ for the year, field notes and work sheets for each site a"e maintained [state where current notes are made available to those working the record or checking the record]. After the record has been completed, field notes ant work sheets are maintained [state where the information is maintained for long-term storage].

[Districts may have specific policies or procedures on which they choose to focus, or unique circumstances they choose to describe or emphasize.]

\section{Sediment Laboratory}

A sediment laboratory [select: is, is not] operated in this District. [If "is not" was selected, delete the remainder of this subsection that pertains to sediment-laboratory activities.] The lab ratory is equipped to [state what types of analyses the laboratory is equipped to perform]. In this laboratory, analyses are performed on samples submitted by [state what offices or groups of individuals send samples to this laboratory]. The laboratory receives a triennial onsite review by appropriate technical or management personnel from the OSW. These reviews examine all aspects of laboratory operations (Knott $\varepsilon$ id others, 1993, p. 14).

[If the District has prepared a laboratory $Q A$ plan or a hygiene plan, reference the documents, state where the documents are maintained, ard present a synopsis of their contents. Include elements of laboratory inspections and how deficiencies are corrected.] 
Primary responsibility for ensuring that appropriate equipment and procedures are used in this laboratory is held by [state RP, such as the Sediment Specialist, Water-Quality Specialist, laboratory chief, or other]. The laboratory is operated according to procedures described in Knott and others (1992) and Guy (1969). Procedures described in the publications, and followed by District personnel, include calibration and maintenance of equipment, analytical procedures, and documentation.

In addition to following guidelines and procedures described in the above-mentioned publications, the District adheres to policies described in memorandums issued by the OSW, OWQ, and WRD. Policy on accepted methods of sediment-size determinations is outlined in Office of Surface Water Memorandum 93.11. Fall diameter is analyzed in this laboratory by use of the [select: pipet method, Sedigraph, or other]. Because the use of asbestos is no longer permitted in a USGS sediment laboratory, when sediment concentrations are determined by the filtration method, the type of filter used is [select: Whatman 934 AH filter, other], as stated in Office of Surface Water Memorandum 92.05.

[Summarize other policies and procedures that ensure effective operation of the sediment laboratory. If appropriate, describe responsibilities associated with specific facets of the work carried out.]

\section{Sediment Station Analysis}

A sediment station analysis is written for each sediment station operated by the District each water year. The sediment station analysis is a summary of the sediment activities at the station for a given year. The analysis describes the coverage of sampling, the types of samples and sampling, changes that might affect sediment transport or the record, and the methods and reasoning used to compute the record. Information included in the sediment station analysis is presented in a thorough manner, such that the checker and the reviewer can determine from the analysis the adequacy of the activities in defining the record and in accomplishing the objectives defined for the station (Office of Surface Water Memorandum 91.15).

Elements included in each sediment station analysis are listed in Office of Surface Water Memorandum 91.15 along with descriptions of the elements and examples. [Describe where or how the station analyses are filed. When are they backfiled? Are there District policies on what additional items are included with the analyses in current files or backfiles? Who is responsible for ensuring the adequacy of the station analyses, including those for individual or special projects?]

\section{Sediment Analysis Results}

[Describe the end products of sediment computations and analyses. Who is responsible for ensuring the quality of the final product? Discuss what sediment data are published, in what publications they are included, and what guidelines are followed for their publication. The District may find it help'ul to reference Novak (1985) and Office of Surface. Water Memorandum 91.15.]

\section{Sediment Data Storage}

[Describe in what form sediment data are stored on a short-term and long-term basis. What is included in the paper files for long-term storage, and wh?re are these files maintained? Who is responsible for ensuring that appropriate information is included in these files? Who is responsible for entering sediment data into the computer data base, and who is respons:ble for ensuring that appropriate data are included in longterm computer storage? How and when are seriment data placed in computer storage reviewed, how are errors detected, and how are these errors corrected? Who is responsible for performing the review, and who is responsible for correcting the problems? Hcw are disagreements between these two parties resolved?]

\section{DATA-BASE MANAGEMENT}

[Surface-water data have been collected by personnel of the WRD and stored in computer data bases for more than 20 years. Proper storage and maintenance of surface-water data are critical comporents in the effective utilization of these data. Because computer hardware and software used in the procersing and storage of surface-water data are continually changing, many Districts hesitate in describing policies and procedures associated with these functions. Dealing with recurring periods of transition, in effect, emphasizes the importance of having clearly assigned authority and clearly stated procedures for correctly populating, updating, reviewing, and maintaining a data base.]

[In this section, describe where surface-и'ater data are stored. Describe what authority personnel should exercise in storing and processing the various types of data. Place emphasis on how finalized data are stored, who is responsible for updating the longterm files, and how the quality of these long-term files is ensured. Statements should address policies and procedures associated with data that include urit values, daily values, peak values, sediment, and basin characteristics. Because offices vary in who holds 
data-base-related responsibilities and how these responsibilities are delegated, present the information in the manner that best describes the local situation. If specific individuals hold certain responsibilities, refer to these individuals by position description rather than by name.]

\section{PUBLICATION OF SURFACE-WATER DATA}

The act of Congress (Organic Act) that created the U.S. Geological Survey in 1879 established the Survey's obligation to make public the results of its investigations and research and to perform, on a continuing, systematic, and scientific basis, the investigation of the geologic structure, mineral resources, and products of the National domain (U.S. Geological Survey, 1986, p. 4). Fulfilling this obligation includes the publication of surface-water data and the interpretive information derived from the analyses of surfacewater data.

\section{Publication Policy}

The USGS and WRD have created specific policies pertaining to publication of data and interpretation of these data. All WRD personnel, including those of this District, are required to abide by these policies. A brief summary of goals, procedures, and policies are presented in U.S. Geological Survey (1986, p. 4-37).

All information obtained through investigations and observations by the staff of the USGS or by its contractors must be held confidential and not be disclosed to others until the information is made available to all, impartially and simultaneously, through Directorapproved formal publication or other means of public release, except to the extent that such release is mandated by law (U.S. Geological Survey, 1986, p. 14). With the approval of the Director, hydrologic measurements resulting from observations and laboratory analyses, after they have been reviewed for accuracy by designated WRD personnel, have been excluded from the requirements to hold unpublished information confidential (U.S. Geological Survey, 1986, p. 15).

All interpretive writings in which the USGS has a proprietary interest, including abstracts, letters to the editor, and all writings that show the author's title and USGS affiliation, must be approved by the Director before release for publication. The objectives of the
Director's review are to final-check the technical quality of the writing and to make certain that it meets USGS publication standards and is consistent with policies of the USGS and Department of the Inter'or. Director's approval ensures that (1) each publication or writing is impartial and objective, (2) has conclu ions that do not compromise the USGS's official position, (3) does not take an unwarranted advocacy positior. and (4) does not criticize or compete with other governmental agencies or the private sector (U.S Geologiral Survey, 1991, p. 10).

[The District may choose to list appropriate District policies related to publication of surfacewater data or to focus on specific USGS or WRD policies.]

\section{Types of Publications}

Various types of book publications released by the USGS are available in which surface-water data and data analyses are presented. Publications of the formal series include the Water-Supply Paper, the Professional Paper, the Bulletin, th: Circular, the Techniques of Water-Resources In/estigations, Special Reports, and Selected Papers in the Hydrologic Sciences (U.S. Geological Survey, 19\& 6, p. 42). Publications in the informal series include the WaterResources Investigations Report, the Open-File Report, and the Administrative Report (U.S. Geological Survey, 1986, p. 52). Included in the Open-File Report series are data reports. Surface-water data collected by this District are published each year in a hydrologic data report that belongs to the annual series entitled "U.S. Geological Survey Water-Data F eports." Factors considered by the District when deciding which form of publication should be utilized in presenting various types of information are presented in Green (1991, p. 14).

\section{Review Process}

Procedures for publication and requirements for manuscript review by the WRD are summarized in U.S. Geological Survey (1991, p. 36-41). This District fulfills these requirements for review and approval of reports prior to printing ar d distribution. All reports written by USGS scientists in connection with their official duties must be approved by the 
originating Division and the Director. At least two technical reviews of each report are required by the WRD (U.S. Geological Survey, 1991, p. 36). Competent and thorough editorial and technical review are the most certain ways to improve and ensure the high quality of the final report (Moore and others, 1990, p. 24). Principles of editorial review and responsibilities of reviewers and authors are presented in Moore and others (1990, p. 24-49). Open-File Reports are not required to receive editorial review, but are reviewed for policy and reproducibility (U.S. Geological Survey, 1991, p. 36).

[The District may further choose to describe local goals, policies, and procedures pertaining to reviews. Are there set procedures or time constraints for authors to respond to colleague reviews? Are there procedures for storing review comments with original manuscripts for future reference once the report has been published?]

[Describe what steps are taken to ensure the quality of the annual data report, from ensuring quality in the original copy and checking the original copy, to checking the final printed report before it is distributed. How is approval for publication and distribution of the annual report achieved? Who is responsible for ensuring quality in the annual data report? Who is responsible for detecting deficiencies, and who is responsible for correcting the deficiencies?]

\section{SAFETY}

Performing work activities in a manner that ensures the safety of personnel and others is of the highest priority for the USGS and the [state the name] District. Beyond the obvious negative impact unsafe conditions can have on personnel, such as accidents and personal injuries, they also can have a direct effect on the quality of surface-water data and data analysis. For example, errors may be made when an individual's attention to detail is compromised when dangerous conditions create distractions. So that personnel are aware of and follow established procedures and policies that promote all aspects of safety, the District communicates information and directives related to safety to all personnel by [state what actions are taken to communicate the information, such as in-house training classes, memorandums, showing videotapes, and other]. Specific policies and procedures related to safety can be found [state where personnel can find this information, such as in the District Safety Plan and other material]. It is the responsibility of each employee to [state what is required of each employee in terms of reading specific memorandums or manuals, attending specific training classes over specific time periods, and other].

An individual has been designated as Safety Officer by [select the District, the area, or other]. The Safety Officer's duties include [state the Safety Officer's responsibilities, type of training the individual receives, and the type of training the individual provides. If the duties related to safety are sha'ed within an area, shared among individuals in sut district offices or field offices, or in other ways, please explain].

Personnel who have questions or concerns pertaining to safety, or who have suggestions for inproving some aspects of safety, should direct those questions, concerns, and suggestions to [state the appropriate individual, such as the personnel's supervisor, the mentioned Safety Officer, a safety con'mittee, or other].

[The District may choose to include other specific items related to safety issues, or place special focus on items contained in the District Safety Plan or other documents.]

\section{TRAINING}

Ensuring that personnel obtain knowledge of correct methods and procedures is a vital aspect of maintaining the quality of surface-water data and data analysis. By providing appropriate training to personnel, the District increases the quality of work ar t eliminates the source of many potential errors.

[Describe how training is provided for personnel by the District. What are the goals of that training? How are training needs determined, and who is responsible for ensuring that training is provided? Does the District have an assigned training officer, and if so, what functions are performed by that position? What role does the supervisor play in the training process? Is there a set of minimum training requirements for various groups of personnel? Is "on-the-job" training an important aspect of District training procedures, and what roles do more experienced personnel play in the process? When personnel identify training needs, what are their responsibilities in seeking the training and who do they contact? When training has been obtained by individuals, how is that training documented?] 


\section{SUMMARY}

Information included in this District Surface Water Quality-Assurance Plan documents the policies and procedures of the [state the name] District that ensure high quality in the collection, processing, storage, analysis, and publication of surface-water data. Specific types of surface-water data discussed in this report include stage, streamflow, sediment, and basin characteristics. The roles and responsibilities of District personnel for carrying out these policies and procedures are presented, as are issues related to management of the computer data base and issues related to employee safety and training.

\section{REFERENCES CITED}

[Include any references cited in the QA Plan. Districts may find it helpful to select from those included in the reference list included at the end of this report.]

\section{APPENDIXES}

\section{Appendix 1. Water Resources Division Memorandums Cited}

[Include any memorandums referenced in this QA Plan that were issued by the USGS, WRD, OWQ, or OSW. Districts may find it convenient to select from those included in the appendix located at the back of this report.]

\section{Appendix 2. District Memorandums Cited}

[Include any memorandums referenced in the QA Plan that were issued by the District.]

[This is the end of the workbook, and this marks the completion of the District Surface Water QualityAssurance Plan.]

\section{CONCLUDING REMARKS}

District offices of the U.S. Geological Survey, Water Resources Division, are required to prepare a District Surface Water Quality-Assurance Plan. The purpose of the plan is to document the policies and procedures that ensure high quality in the collection, processing, storage, analysis, and publication of surfacewater data. This report serves as a structural template to assist Districts in the preparation of their plans.
REFERENCES CITED

Arcement, G.J., and Schneider, V.R., 1989, Guide for selecting Manning's roughness coefficients for natural channels and flood plains: U.S. Geological Survey WaterSupply Paper 2339, $38 \mathrm{p}$.

Barnes, H.B., 1967, Roughness characteristics of natural channels: U.S. Geological Survey Water-Supply Paper 1849, $213 \mathrm{p}$.

Benson, M.A., and Dalrymple, Tate, 1967, General field and office procedures for indirect discharg measurements: U.S. Geological Survey Techniques of WaterResources Investigations, book 3, chap. A 1, 30 p.

Bodhaine, G.L., 1982, Measurement of pe ${ }^{2 k}$ discharge at culverts by indirect methods: U.S. Geological Survey Techniques of Water-Resources Investigations, book 3 , chap. A3, $60 \mathrm{p}$.

Buchanan, T.J., and Somers, W.P., 1969, D'scharge measurements at gaging stations: U.S. Geological Survey Techniques of Water-Resources Investigations, book 3, chap. A8, 65 p.

Carter, R.W., and Davidian, Jacob, 1968, Goneral procedures for gaging streams: U.S. Geological Survey Techniques of Water-Resources Investigations, book 3, chap. A6, $13 \mathrm{p}$.

Dalrymple, Tate, and Benson, M.A., 1967, Measurement of peak discharge by the slope-area metl $x$ : U.S. Geological Survey Techniques of Water-Resources Investigations, book 3, chap. A2, 12 p.

Davidian, Jacob, 1984, Computation of water-surface profiles in open channels: U.S. Geological Survey Techniques of Water-Resources Investigations, book 3 , chap. A15, 48 p.

Edwards, T.K., and Glysson, G.D., 1988, Field methods for measurement of fluvial sediment: U.S. Geological Survey Open-File Report 86-531, $118 \mathrm{p}$.

Green, J.H., 1991, WRD project and report management guide: U.S. Geological Survey Open-File Report 91-224, 152 p.

Guy, H.P., 1969, Laboratory theory and mathods for sediment analysis: U.S. Geological Survey Techniques of Water-Resources Investigations, brok 5, chap. $\mathrm{Cl}$, $58 \mathrm{p}$.

Guy, H.P., 1970, Fluvial sediment concepts: U.S. Geological Survey Techniques of Water-Resources Investigations, book 3, chap. $\mathrm{Cl}, 55 \mathrm{p}$.

Guy, H.P., and Norman, V.W., 1970, Field methods for measurement of fluvial sediment: U.S. Geological Survey Techniques of Water-Resources Investigations, book 3 , chap. $2,59 \mathrm{p}$.

Hubbard, E.F., 1992, Policy recommendations for management and retention of hydrologic data of the U.S. Geological Survey: U.S. Geological Sur'ey Open-File Report 92-56, 32 p. 
Kennedy, E.J., 1983, Computation of continuous records of streamflow: U.S. Geological Survey Techniques of Water-Resources Investigations, book 3, chap. A13, $53 \mathrm{p}$.

1984, Discharge ratings at gaging stations: U.S. Geological Survey Techniques of Water-Resources Investigations, book 3 , chap. A $10,59 \mathrm{p}$.

1990, Levels at streamflow gaging stations: U.S. Geological Survey Techniques of Water-Resources Investigations, book 3, chap. A 19, 31 p.

Kilpatrick, F.A., and Schneider, V.R., 1983, Use of flumes in measuring discharge: U.S. Geological Survey Techniques of Water-Resources Investigations, book 3, chap. A14, 46 p.

Knott, J.M., Glysson, G.D., Malo, B.A., and Schroder, L.J., 1993, Quality assurance plan for the collection and processing of sediment data by the U.S. Geological Survey, Water Resources Division: U.S. Geological Survey Open-File Report 92-499, 18 p.

Knott, J.M., Sholar, C.J., and Matthes, W.J., 1992, Quality assurance guidelines for the analysis of sediment concentration by the U.S. Geological Survey sediment laboratories: U.S. Geological Survey Open-File Report 92-33, 22 p.

Matthai, H.F., 1967, Measurement of peak discharge at width contractions by indirect methods: U.S. Geological Survey Techniques of Water-Resources Investigations, book 3, chap. A4, $44 \mathrm{p}$.

Moore, J.E., Aronson, D.A., Green, J.H., and Puente, Celso, 1990, Report planning, preparation, and review guide: U.S. Geological Survey Open-File Report 89-275, $81 \mathrm{p}$.

Novak, C.E., 1985, WRD data reports preparation guide, U.S. Geological Survey Water-Resources Investigations, book 3, chap. C3, 66 p.

Porterfield, George, 1972, Computation of fluvial-sediment discharge: U.S. Geological Survey Techniques of
Water-Resources Investigations, book 3, chap. C3, $66 \mathrm{p}$.

Rantz, S.E., and others, 1982, Measurements and computation of streamflow, volumes 1 and 2: U.S. Geological Survey Water-Supply Paper 2175, $631 \mathrm{p}$.

Sauer, V.B., and Meyer, R.W., 1992, Determination of errors in individual discharge measurements: U.S. Geological Survey Open-File Report 92-144, 21 p.

Schroder, L.J., and Shampine, W.J., 1992, Guidelines for preparing a quality assurance plan for the district offices of the U.S. Geological Survey: U.S. Geological Survey Open-File Report 92-136, 14 p.

Shampine, W.J., Pope, L.M., and Koterba, M.T., 19?, Integrating quality assurance in project work plans of the U.S. Geological Survey: U.S. Geological Survey Open-File Report 92-162, $12 \mathrm{p}$.

Shearman, J.O., 1990, User's manual for WSPROA computer model for water surface profile computations: U.S. Federal Highway Administration Feport, FHWA-IP-89-027, $187 \mathrm{p}$.

Smoot, G.F., and Novak, C.E., 1968, Calibration and maintenance of vertical-axis type current meters: U.S. Geological Survey Techniques of Water-Resources Investigations, book 8, chap. B2, 15 .

U.S. Geological Survey, 1986, Water Resources Division publications guide; Volume I, Publications policy and text preparation $(2 \mathrm{~d}$ ed.), revised $b y$ D.W. Alt and K.T. Iseri: U.S. Geological Survey Open-File Report 87-0205, $429 \mathrm{p}$.

1991, Suggestions to authors of the reports of the United States Geological Survey (7th ed.), revised and edited $b y$ W.R. Hansen: U.S. Geological Survey' special book publication, $289 \mathrm{p}$. 
APPENDIX 


\section{Appendix}

The following memorandums were cited in this report. The memorandums are provided in their entirety in a separate report by the Office of Surface Water.

93.12 Office of Surface Water memorandum

93.11 Office of Surface Water memorandum

93.07 Office of Surface Water memorandum

93.01 Office of Surface Water memorandum

92.11 Office of Surface Water memorandum

92.10 Office of Surface Water memorandum

92.09 Office of Surface Water memorandum

92.08 Office of Surface Water memorandum

92.05 Office of Surface Water memorandum

92.04 Office of Surface Water memorandum

91.15 Office of Surface Water memorandum

91.09 Office of Surface Water memorandum

90.10 Office of Surface Water memorandum

90.08 Office of Surface Water memorandum

90.01 Office of Surface Water memorandum

89.08 Office of Surface Water memorandum

89.07 Office of Surface Water memorandum

88.18 Office of Surface Water memorandum

88.17 Office of Surface Water memorandum

88.07 Office of Surface Water memorandum

87.05 Office of Surface Water memorandum

85.17 Office of Surface Water memorandum

84.05 Office of Surface Water memorandum

83.07 Office of Surface Water memorandum

92.59 Water Resources Division memorandum

77.83 Water Resources Division memorandum

77.60 Water Resources Division memorandum

71.73 Water Resources Division memorandum

80.17 Office of Water Quality memorandum

80.07 Office of Water Quality memorandum

79.17 Office of Water Quality memorandum

77.07 Office of Water Quality memorandum

76.17 Office of Water Quality memorandum

76.04 Office of Water Quality memorandum

Memorandum from the Chief, Branch of Operational Support, May 7, 1993 